\title{
BAJO LA MÁSCARA DE LA "REVUELTA IXTEPEJANA”. UNA ALEGORÍA REVOLUCIONARIA REVISADA
}

\author{
Tatiana Pérez Ramírez \\ El Colegio de México
}

\section{INTRODUCCIÓN}

-126 de mayo de 1912 se dio a conocer un plan político conEtra el gobierno de Francisco I. Madero en la Sierra Juárez de Oaxaca. En esa carta “A la Nación”, "los hijos de la Sierra Juárez” anunciaban que se levantaban en armas, sostenían el Plan de San Luis reformado en Tacubaya y desconocían a las autoridades que apoyaban al presidente. Aunque esta sierra está algo lejos del estado de Chihuahua, los levantados decían reconocer y "sujetarse" a las disposiciones de Pascual Orozco. Sin dejar de lado algunas demandas locales, se pedía la reducción del pago al impuesto de capitación a no más de 12 centavos (mensuales). Las tropas adherentes al documento decían conducirse con honradez y llamaban a tomar las armas "para mejorar [su] triste condición de oprimidos” y para que la historia no contara que "los valientes oaxaqueños nos dejamos humillar vergonzosamente por el tirano Francisco I. Madero”. ${ }^{1}$

Fecha de recepción: 9 de mayo de 2019

Fecha de aceptación: 24 de octubre de 2019

${ }^{1}$ AHCCJO, leg. 519, exp. 3, f. 68. 
Este documento, que en algunas misivas se conoció como el "Plan de Ixtepeji”, circuló a través de la cordillera al menos en 16 municipios del distrito de Ixtlán en semanas sucesivas. Al final del texto se encontraban las firmas de dos serranos que se declaraban "jefes revolucionarios" del "Ejército Libertador": Pedro León, comerciante y político antirreeleccionista de la agencia municipal de San Pedro Nexicho, y Juan Martínez Carrasco, presidente municipal de Santa Catarina Ixtepeji. ${ }^{2}$

Ese día 26, en El Avance, uno de los diarios de la ciudad de Oaxaca, se publicó en primera plana una nota que decía: “Sierra Juárez en abierta rebelión”. No se mencionaba nada sobre el plan político, pero se narraba que unos días antes -el 22 de mayo de 1912- se presentaron unos hombres armados en la cabecera de Ixtlán y asesinaron a algunos integrantes del cabildo, nombraron a un jefe político provisional, y en una fábrica -ubicada en la localidad de Xía-fusilaron al jefe político destituido junto con su secretario. Horas después, los serranos comenzaron a desplazarse hacia San Felipe del Agua (un pueblo que se encuentra en el distrito del Centro y en las inmediaciones de la ciudad de Oaxaca e Ixtepeji), en donde pidieron provisiones a la población. Según la información había rumores de que los “insurrectos” destruirían el acueducto de San Felipe y los hilos que conducían la fuerza eléctrica de Vista Hermosa. ${ }^{3}$

Ante las noticias que se divulgaban en los medios impresos y otros informantes, el cabildo de la ciudad de Oaxaca se reunió para evaluar el posible escenario de crisis. En el acta del 27 de mayo de 1912, el regidor Esteva mencionaba que esa mañana a las nueve horas los serranos sublevados habían cortado los

${ }^{2}$ Conviene mencionar que Nexicho es agencia municipal de Ixtepeji. Este municipio era conocido por su esplendor en el periodo colonial, cuando fue uno de los pueblos de indios más importantes de la Sierra por la explotación de la grana cochinilla. En el siglo xx, todavía tenía una numerosa población, aún mayor que Ixtlán, la cabecera del distrito.

3 BFFB, $M B C, H$, núm. 11, Avance (26 mayo 1912). 
acueductos de San Felipe y de San José. En esa misma relatoría, el ingeniero Woolrich, jefe de las obras de saneamiento, mostraba la ubicación de fuentes alternas de abastecimiento en caso de una emergencia mayor. También se dictaban disposiciones para mandar guardias hacia los distintos afluentes de agua de la urbe. ${ }^{4}$

En la ciudad de México, el Imparcial publicaba que, desde una ciudad casi desierta en donde el "pánico" era "indescriptible", el movimiento revolucionario de Pedro León, de la Sierra de Ixtlán, proveniente de los rumbos del norte y noroeste, había estado a menos de dos leguas (aproximadamente nueve kilómetros y medio) de la Plaza de Armas de Oaxaca. Según este diario, los serranos se acercaban a la "gotera de la capital". Al enfrentamiento llegaron los cuerpos de rurales, pero éstos no lograron hacerlos retroceder. Además, los serranos eran numerosos y estaban bien armados con "maussers". Esta situación recordaba al público el inicio de la revolución de Tuxtepec en 1876, cuando en tres horas los serranos entraron a la ciudad. ${ }^{5}$

En los acervos judiciales se encuentran descripciones de la invasión de otros serranos por el rumbo de Huayápam, un poco más al noreste. ${ }^{6}$ Por su parte, en los informes militares se registró el resguardo de la ciudad con la participación de un cuerpo de rurales y otro de voluntarios que se desplazaron hacia la zona de las incursiones y posteriormente llegaron las tropas del $12^{\circ}$ regimiento con algunas compañías de auxiliares. Después de un enfrentamiento intermitente durante el día 27 de mayo y algunas escaramuzas en las inmediaciones de la ciudad los días 28, 29 y 30 de mayo, los llamados rebeldes no lograron su objetivo y se regresaron a la Sierra Juárez. ${ }^{7}$

La actividad armada en ese lugar continuó en las semanas siguientes. Algunos municipios liderados por Ixtepeji se

${ }^{4}$ AHMO, SM, ACO, lib. 100, exp. 24, ff. 58v., 61r.

5 El Imparcial (27 mayo 1912), p. 5. El Imparcial (28 mayo 1912), p. 1.

6 AHCCJO, A, leg. 711, exps. 1-16.

7 AHSDN, c. 110 , exp. XI/481.5/207, ff. 505-511 y 550-555. 
enfrentaron a otros municipios aliados con Ixtlán. Al menos durante seis meses se vivieron turbulencias en este distrito con la intervención de las fuerzas armadas del estado. En septiembre otro contingente atacó nuevamente y sin éxito a la ciudad de $\mathrm{Oa}$ xaca. A inicios de noviembre de 1912 el ejército federal derrotó a estos disidentes. ${ }^{8}$ Hasta aquí se cierra el acontecimiento que se denominó "la revuelta ixtepejana”.

La historiografía regional ha dedicado algunas páginas a este conflicto como una de las revueltas del periodo que antecedió al nombrado "movimiento de la soberanía"; este último se conoce como una manifestación política y militar contra Venustiano Carranza en los años de 1915 a 1920 en donde se declaró la soberanía del estado de Oaxaca. Dicho acontecimiento se plasma en los libros de los historiadores Paul Garner y Francisco José Ruiz Cervantes. El tema central de ambos trabajos es el análisis de 1915 a 1920, pero se plantea el problema de 1912 en la Sierra Juárez. ${ }^{9}$ De los años ochenta, que fue cuando se produjeron los dos libros citados, a la fecha, encontramos un artículo publicado por Carlos Sánchez Silva sobre el conflicto intercomunal en la Sierra Juárez en donde se elabora un análisis más puntual de mayo a noviembre de $1912 .{ }^{10}$

Grosso modo, y con ciertos matices, estos trabajos ubicaron a la "rebelión ixtepejana" como un levantamiento armado producto de los ixtepejanos, comandados por Pedro León y Juan Martínez Carrasco. Este grupo de rebeldes atacó la cabecera del distrito en la coyuntura de la Revolución, pero en el telón de

8 Sánchez Silva, "Conflicto intercomunal”, p. 121. Amado Pérez (s/f), “Apuntes sobre la revuelta orozquista-serrana-ixtepejana de 1912", manuscrito, pp. 20 y 27. Garner, La Revolución en la provincia, pp. 86-88. RuIZ Cervantes, La revolución en Oaxaca, pp. 38-39. AHSDN, c. 111, exp. XI/481.5/207, ff. 872-874, 877-880, 1167-1168.

9 Ruiz Cervantes, La revolución en Oaxaca. Garner, La Revolución en la provincia.

10 SÁnchez Silva, "Conflicto intercomunal”. 
fondo estuvieron las viejas rencillas que databan de siglos atrás. Según esto, había dos pueblos antagónicos (Ixtlán e Ixtepeji) y sus añejos conflictos estallaron en el contexto revolucionario nacional y ante la inestabilidad política estatal.

Estas investigaciones se acercaron a los problemas entre las comunidades y al escenario en donde surgió esta rebelión, pero no profundizaron en sus demandas ni en otros actores involucrados. Esas interpretaciones coinciden con las fuentes periodísticas de la época al señalar la presencia, acción y movilización de los rebeldes al levantarse contra el gobierno, al enfrentarse a las tropas del ejército en la Sierra y en los momentos de asalto a la ciudad de Oaxaca. Si se revisan estos escritos encontramos que hay muchos sublevados contra el gobierno en donde se habla de pueblos y de indios, pero no se analiza qué pedían y por qué tomaron las armas en ese momento. Esta lectura de la "revuelta ixtepejana", si bien innovadora para su tiempo, se ha cristalizado desde los años ochenta hasta nuestros días.

Si tomamos distancia de esa narrativa de la historia regional, ya con hallazgos recientes y con las discusiones sobre la heterogeneidad de la Revolución y los procesos locales en momentos de inestabilidad política, tal vez podamos observar algunos otros aspectos de un acontecimiento aparentemente poco cuestionado. Si volvemos a revisar este fenómeno bajo otras claves, podríamos encontrar un resultado distinto.

En primer lugar, hay que problematizar aún más lo que ya se sabe. Por ejemplo, contamos con algunos datos de los hombres que firmaron el plan mencionado en la primera página de este texto, pero desconocemos los detalles sobre la elaboración y la redacción del escrito. Dado lo anterior, surgen algunas interrogantes: ¿Por qué levantarse en armas en ese momento y de esa forma? ¿Cómo se construyó su discurso político? ¿Qué pedían y cómo se organizaron?

Hace décadas no había información detallada para responder a cuestiones puntuales. Pero para fortuna de quien escribe, y 
como resultado de las pesquisas en los expedientes judiciales, contamos con los procesos de los detenidos e involucrados en este levantamiento. Aunque el material documental permite ver varios aspectos de este fenómeno, me concentro en el inicio de este levantamiento armado. Presento la descripción y el análisis del discurso de los líderes mediante los planes políticos que se elaboraron a modo de convocatorias y cordilleras en el primer mes de movilizaciones en la Sierra Juárez. Así, podemos ver cómo se fue gestando el movimiento y qué era lo que pedían en un contexto determinado. A la luz de esto, se advierte la transformación de estos cabecillas y sus demandas. En consecuencia, se pone en duda la vigencia del uso de la denominación de la "revuelta ixtepejana” para este fenómeno político.

Al situar a este proceso en el plano de la historiografía nacional, es pertinente comentar que partimos de una posición crítica a la idea monolítica de la revolución, como se vino haciendo en las últimas décadas del siglo xx, ${ }^{11}$ pero se advierte que aún hace falta para modificar esa imagen (especialmente en Oaxaca). La historiografía oaxaqueña ya mencionada párrafos arriba desveló las características generales de la organización política y la actividad armada en el estado; sin embargo, aún queda pendiente sumergirnos en el ámbito regional y local.

En ese sentido retomo la idea del historiador Alan Knight, quien hace años señaló que los pueblos aprovecharon la

${ }^{11}$ La historiografía de la revolución mexicana es extensa. Cito algunas de las revisiones historiográficas que muestran el cambio generado en la interpretación de la revolución mexicana a finales de la década de 1970 en Benjamin, "La Revolución es regionalizada”; Luis González, "La Revolución Mexicana y los revolucionados”, en Nexos (1a ago. 1986). FALCÓN, "Las revoluciones mexicanas de 1910"; FALCón, "El revisionismo revisado"; KNIGHT, "La revolución mexicana”, Womack, "La Revolución Mexicana”, p. 78. Joseph, Aspectos cotidianos, pp. 31-40. Algunas publicaciones que abonan a presentar la diversidad de movimientos y levantamientos en los años de guerra: FALCón, Revolución y caciquismo; JACOBs, La revolución mexicana en Guerrero; Joseph, La revolución desde afuera; Almada BAY, La conexión Yocupicio. 
Revolución como un momento catalizador de los conflictos locales. ${ }^{12}$ Ahora bien, en el presente escrito examino a los dirigentes que escribían en nombre de esos "pueblos" de la Sierra Juárez y sostengo que los cabecillas de los grupos disidentes (Pedro León y Juan Martínez Carrasco) tomaron la bandera de la Revolución y adaptaron su discurso político para no ser apresados y así sacar ventaja frente a sus enemigos. Más allá de las motivaciones ideológicas o las causas nacionales, estas acciones estuvieron en función de sus intereses políticos locales y de los cambios en la coyuntura. Claro está que este levantamiento no triunfó y forma parte de esos innumerables movimientos derrotados y poco conocidos.

Para demostrar lo anterior, se analizan los documentos de los líderes de este levantamiento armado no victorioso con la finalidad de ver la diversidad de las causas, las motivaciones y los actores que participaron en esta llamada "revuelta ixtepejana". Pero esta propuesta no se limita a la descripción de dicha heterogeneidad, sino que también se hace un esfuerzo analítico y conceptual. Por ello, esta relectura cuestiona si aún es pertinente nombrarla "revuelta" y si fue exclusivamente "ixtepejana".

Antes de pasar al desarrollo de esta problemática es oportuno hacer ciertas precisiones. En las páginas precedentes se ha hablado de la Sierra Juárez, pero no se ha dicho en qué parte de Oaxaca se ubica ni se han mencionado sus características. Algo que destaca de este espacio es el medio físico dominado por sus cerros y sus montes que forman parte del conjunto montañoso de la Sierra Madre Oriental, cuyas elevaciones varían de los 1800 a 3000 metros sobre el nivel del mar. ${ }^{13}$ En este paisaje se destacan los cerros "La Cumbre", "Humo Chico", "Humo Grande", "El Pelón”, "El Cuachirindó”, "El Cerro del Pájaro”, "El Cerro Perico" y "El Machin".

12 KNIGHT, La revolución mexicana, p. 520.

13 Guevara Hernández, “Arqueología de la Sierra Juárez”, pp. 334-341. 
El Río Grande es el principal afluente de esta zona, que atraviesa la montaña con vertientes y riachuelos que llegan a distintas localidades. Algunas de estas corrientes subterráneas desembocan en el Alto Papaloapan. El historiador Bernardo García Martínez denominó a esta región "Sierra Zapoteca", ubicada dentro de la Vertiente del Golfo. ${ }^{14}$ No obstante, con la información, el trabajo de campo y el análisis recientes es posible replantear esta denominación puesto que en este espacio también hay población chinanteca de la montaña. Entonces, no es sólo zapoteca. ${ }^{15}$

Si se observa desde el tiempo largo, se encuentra que este lugar estuvo habitado por grupos zapotecos y fue una frontera cultural étnica y de intercambio con la población chinanteca desde el periodo Clásico. Hay evidencias arqueológicas de que ahí se constituyó un corredor que comunicó la parte del centro de Oaxaca con las planicies de la Cuenca del Papaloapan. ${ }^{16}$ En la etapa colonial, en ese lugar se congregó a los pueblos de indios que, después de fragmentaciones y cambios, dieron vida a los municipios del periodo del México independiente hasta la actualidad.

Ya expuestos los rasgos del medio físico y la población, es necesario aclarar que estos dos elementos por sí mismos no nos dan una región. Considérese que el concepto de región se entiende como un espacio funcional que resulta de un intrincado proceso relacional sociopolítico, económico y cultural que va cambiando y redefiniéndose en el transcurso del tiempo. No es inmutable ni estático y su transformación depende de una

\footnotetext{
14 García Martínez, Las regiones de México, pp. 106-107.

15 En los viajes de campo que realicé con el doctor Bernardo García Martínez a la Chinantla y a la Sierra Juárez se planteó la idea de que era necesario actualizar esa denominación de "la Sierra Zapoteca” puesto que había suficientes evidencias de los nexos y conexiones interétnicas de zapotecos y chinantecos en este espacio.

16 Guevara Hernández, “Arqueología de la Sierra Juárez”, pp. 334-341.
} 
gama de factores (internos y externos). Aunque el territorio es una parte importante, los criterios para definir una región pueden tomarse a partir de la distribución y el tipo de producción económica, la estructura política, el intercambio comercial, las relaciones mercantiles, entre muchas otras. En nuestro caso de estudio, además de los rasgos ya expuestos, se consideran dos variables: la organización política y la participación armada. ${ }^{17}$

Conviene ahondar un poco más en esto. Aquí se habla de la Sierra Juárez como un sistema espacial moderno que resultó de la reconfiguración del mundo nohovispano y la formación del México independiente. Este espacio estaba dominado por Villa Alta, pero en el siglo XIX, el municipio de Ixtlán emergió como el lugar preeminente y en jerarquía política mayor ante esta Villa y otros dos antiguos pueblos de indios poderosos: Ixtepeji y Teococuilco. Esta posición relevante se mostró en 1858 con el establecimiento del distrito político de Ixtlán. Pero es necesario aclarar que esta región no resultó exclusivamente por dicha demarcación administrativa.

$\mathrm{Al}$ menos, de lo que se tiene registrado, a partir de 1855 Ixtlán fue el centro de organización política y armada en donde se formaron batallones y guerrillas que estuvieron activas en el periodo de la Guerra de Reforma, la Intervención Francesa, el Segundo Imperio y el Plan de Tuxtepec. A esto se puede sumar la conformación de un caudillaje político y militar relacionado con la explotación de la minería. ${ }^{18}$ En este lugar se formaron

17 García Martínez, “México”, p. 20. García Martínez, Las regiones de México, p. 29.

18 La historiografía del siglo xix sobre la Sierra Juárez no es abundante, pero se encuentran los trabajos de McNamara, Sons of the Sierra, en donde se estudia la formación de las milicias serranas desde la Guardia Nacional de 1855 hasta el declive del porfiriato en 1911. Además, McNamara presenta el estudio de un dirigente de la agencia municipal de Guelatao. McNamara, Sons of the Sierra; McNamara, “Felipe García”, pp. 111-130. Por su parte, Brian Hamnett explora la formación de una élite a partir de la explotación de los minerales de la Sierra Juárez. Hamnetт, “The Caciques”, pp. 111-130. 
nexos con Benito Juárez, nacido en la agencia de Guelatao en el municipio de Ixtlán, y con Porfirio Díaz, quien fue subprefecto político en Ixtlán en 1855 y formó la primera guardia nacional. De lo anterior se puede pensar que este sistema espacial fue delimitado en términos administrativos y que en el transcurso de la segunda mitad del siglo XIX se expandió dependiendo de los vínculos entre municipios en tanto a la organización política y la participación armada del periodo de guerras.

Registrado esto, a continuación se muestra qué sucedió en estos municipios al inicio del periodo revolucionario y después se hace un primer acercamiento a los principales dirigentes que encabezaron ese levantamiento armado, quienes lograron articular un discurso ad hoc a la coyuntura y presentaron interesantes proclamas.

\section{DE MILICIANOS JUARISTAS A REVOLUCIONARIOS}

En el año de 1910, cuando numerosas voces opositoras al régimen del presidente Porfirio Díaz se unían a la campaña de Francisco I. Madero y aprovechaban el momento para denunciar y dar a conocer sus demandas locales, en la Sierra Juárez -por lo que se sabe hasta el momento- no se gestó un movimiento disidente, como ocurrió en Cuicatlán, Etla, Ojitlán o incluso en la Costa.

No obstante, este lugar no estaba exento de acomodos políticos y cierta inestabilidad. Por un lado, los caudillos regionales Fidencio Hernández y Guillermo Meixueiro convocaron a la formación de un batallón a favor de Díaz. ${ }^{19}$ Esta propuesta no

19 Estos dos personajes eran herederos del poder político y económico de sus padres, los caudillos serranos Fidencio Hernández y Francisco Meixueiro, ambos encumbrados no sólo por su participación en la guerra sino por el desarrollo de la minería y la fábrica de textiles. Sobre el surgimiento de estas familias véase HAMnETT, “The Caciques”, pp. 111-130. Un estudio más extenso sobre el tema del caudillaje en donde se hace referencia al caso de la Sierra Juárez 
tuvo respaldo y fue criticada. ${ }^{20}$ Por otro lado, en ese contexto se apoyó a Francisco I. Madero y, curiosamente, cobró fuerza Benito Juárez Maza, el hijo del benemérito, quien era el candidato a la gubernatura del estado en ese año y quien se acercó a algunos de sus "paisanos" en busca de respaldo. Con esto se hacía visible una división entre los grupos porfiristas y otros antirreeleccionistas en la cabecera distrital de Ixtlán. ${ }^{21}$

Aunado a lo anterior, se reportó un intento de rebelión en 1910. Sin entrar en detalles, en esa acción estuvo involucrado Pedro León, aquel personaje que firmó el documento descrito al inicio de este ensayo. Este hombre era partidario de Madero y participante de la campaña de Juárez Maza a la gubernatura. ${ }^{22}$ No hay suficiente información, pero se menciona que en 1910 a Pedro León lo detuvieron acusado del delito de rebelión junto con su aliado, Miguel Hernández, quien era oriundo de Ixtlán, trabajador ferrocarrilero en las líneas de Hidalgo y del Noroeste que se incorporó también al antirreeleccionismo. El otro cómplice fue Pedro Castillo, de Quiotepec, quien no fue detenido. ${ }^{23}$ Se sabe poco de este hecho, sólo hay registros de que sus dirigentes fueron apresados. Pese a lo enigmático del caso, estos personajes estuvieron activos en la política local en los años inmediatos.

En el curso de 1911, ya cuando Díaz había renunciado, fue relevante el triunfo de Benito Juárez Maza como gobernador del

en Knight, "Caudillos y campesinos”, pp. 47-59. Garner, "Federalism and Caudillismo”, pp. 111-133.

20 Ibarra, Memorias, p. 30. Chassen, Oaxaca, p. 620. AHCCJO, J, leg. 485, exp. 4, $37 \mathrm{f}$.

21 Pérez García, Una revolución de ocho meses, p. 31.

22 Pérez García, Una revolución de ocho meses, p. 31. La filiación antirreeleccionista de Pedro León también la menciona Francisco José Ruiz Cervantes. Ruiz Cervantes, La revolución en Oaxaca, p. 34.

23 Arellanes Meixueiro, Chassen et al., Diccionario histórico, pp. 18, 113 y 128. Las versiones contradictorias de este suceso se mencionan. MARTínez Medina, “Génesis y desarrollo”, pp. 107-108. Chassen, Oaxaca, p. 614. 
estado de Oaxaca, cuyo periodo inició el 23 de septiembre de 1911. Una de las acciones de gobierno que nos interesa fue la formación de una milicia de pobladores nombrada el Batallón Sierra Juárez. El origen y la interesante composición de este afamado batallón ha sido tema de algunos historiadores oaxaqueños, pero aún merece mayor atención e indagación..$^{24}$ Sobre las discusiones de los motivos y las formas de la convocatoria a estos pobladores, es pertinente mencionar que recientemente hay consenso -especialmente por lo dicho por Ruiz Cervantesde que Juárez Maza llamó a sus "paisanos" con la finalidad de formar un cuerpo armado de su confianza para su protección ante la inestabilidad política que se vivía en el estado de Oaxaca. Considérese que para ese tiempo había un problema apremiante en Juchitán, donde el conocido líder “Che Gómez” encabezaba un levantamiento armado..$^{25}$

En la historiografía oaxaqueña se narra que esta fuerza armada estuvo organizada en tres compañías. La primera tenía a la cabeza a Pedro León, de Ixtepeji; en la segunda estaba Onofre Jiménez, de Ixtlán, y el tercer grupo estuvo a cargo del capitán Isaac Ibarra, de Lachatao; este último es un municipio que forma parte de los "pueblos mancomunados" ${ }^{26}$ En este punto conviene agregar que la integración del Batallón fue más heterogénea que lo mencionado por esta historiografía, al menos

${ }^{24}$ Martínez Vásquez, La revolución en Oaxaca, pp. 183-184. Garner, La Revolución en la provincia, p. 84. Ibarra, Memorias, p. 36. Ruiz Cervantes, "El Batallón Sierra Juárez", p. 17.

${ }^{25}$ Francisco Ruiz Cervantes basa su interpretación en el análisis del contexto político y a partir de la correspondencia entre el gobernador y los dirigentes del Batallón. Ruiz Cervantes, "El Batallón Sierra Juárez”, pp. 16 y 18. Sobre la situación de Juchitán véase GARNer, La Revolución en la provincia, pp. 75-77. Ruiz Cervantes, La revolución en Oaxaca, pp. 28-32. Purnell, "The Chegomista Rebellion”, pp. 51-70.

${ }^{26}$ Martínez Vásquez, La revolución en Oaxaca, pp. 183-184. Garner, La Revolución en la provincia, p. 84. Ibarra, Memorias, p. 36. Ruiz Cervantes, "El Batallón Sierra Juárez", p. 17. 
eso se encontró en la conformación de la primera compañía. En los acervos estatales hay evidencias de que ese grupo comandado por Pedro León, quien es un personaje principal en esta historia, se formó por pobladores de distintos municipios de la región. ${ }^{27}$ Advierto de antemano que este dato no es menor, ya que esta compañía aparece de manera relevante en páginas siguientes porque al disolverse el Batallón, al mes y medio de su creación, en la ciudad de Oaxaca, quedó esta primera compañía mientras las otras dos regresaron a la Sierra. Las implicaciones de este suceso incidieron en la situación política de la capital y sus alrededores.

En diciembre de 1911, en la cabecera municipal de Tlalixtac de Cabrera, se dio una confrontación donde estuvieron involucrados los integrantes de la primera compañía. Las referencias a este incidente apuntan a que Pedro León fue con su gente a atender un problema en ese lugar con el objetivo de poner orden. Por el contrario, comenzó una balacera que cobró la vida en su mayoría de pobladores de Tlalixtac. La situación se recrudeció aún más porque los involucrados en la contienda tenían problemas antiguos por límites de tierras. Se abrió un proceso legal contra la gente comandada por Pedro León a inicios de 1912, pero no hubo castigo inmediato. ${ }^{28}$

Por ello, se especuló que los serranos tenían la venia del gobernador Benito Juárez Maza, ${ }^{29}$ quien había estado ocupado por el conflicto político en Juchitán. ${ }^{30}$ Para la mala suerte de estos serranos, su protector, el hijo de Juárez, falleció súbitamente el

27 AGEO, C y P, leg. 1, exp. 16, s/f.

${ }^{28}$ Lo sucedido en Tlalixtac tiene sus claroscuros. Algunas menciones sobre esto en Jiménez, Memorias, p. 12. Ibarra, Memorias, p. 38. Martínez MediNA, "Génesis y desarrollo", p. 142.

${ }^{29}$ AGEO, C, leg. 62, exp. 17, s/f.

30 Garner, La Revolución en la provincia, pp. 75-77. Ruiz Cervantes, La revolución en Oaxaca, pp. 28-32. Purnell, "The Chegomista Rebellion", pp. $51-70$. 
20 de abril de 1912. Acto seguido, los serranos se escaparon de la ciudad de Oaxaca la madrugada del día 26 de abril. Un mes después se difundía que la Sierra Juárez se había levantado en armas contra el gobierno, la cabecera distrital había sido invadida y los rebeldes se acercaban a la ciudad de Oaxaca. ¿Cómo sucedió esto?

\section{LA HUIDA:}

EVASIÓN A LA LEY CON UNA PIZCA DE VENGANZA

Sobre la huida de los serranos después del 21 de abril de 1912 abundan las especulaciones. La versión más divulgada apunta a que ante la desprotección por la muerte del gobernador, Benito Juárez Maza, la primera compañía del Batallón Sierra Juárez huyó de la ciudad de Oaxaca por temor a una posible represalia del gobierno. El mismo Pedro León, en entrevista con Humberto L. Strauss, del diario El Imparcial, dijo que cuando "su amigo don Benito Juárez” falleció, el jefe político del Centro, Constantino Chapital, le avisó que lo iban a aprehender por lo ocurrido en Tlalixtac. Por eso, en la mañana salió rumbo a la Sierra Juárez y en el paraje de La Cumbre lo alcanzaron sus hombres. El entrevistado decía que no tenía "la culpa de que desertaron”. Además, agregaba: don Benito le había dicho que las armas serían para ellos cuando cumplieran el plazo y cuando murió no tenían nada que hacer en Oaxaca. ${ }^{31}$

Como se puede ver, el capitán de la primera compañía aceptaba que la salida de Oaxaca había sido por un probable arresto derivado de las acusaciones legales por los abusos de su tropa en Tlalixtac en diciembre de 1911. Pero la huida había sido individual y él no había alentado a sus hombres. Ellos le dieron alcance por cuenta propia. A propósito del escape, además de lo dicho por el propio León, se comentó lo siguiente. Onofre

${ }_{31}$ AHCCJO, C, leg. 517, exp, 7, f. 60. El Imparcial (19 jun. 1912). 
Jiménez, quien era ixtleco y vinculado con un grupo de antirreeleccionistas, jefe de la segunda compañía, cuenta que la primera compañía del Batallón Sierra Juárez huyó porque Alberto Montiel, el gobernador interino, libró una orden de aprehensión contra Pedro León y el desarme de su gente. Al enterarse de esta noticia, el capitán Pedro León se escapó la noche del 26 de abril de 1912 con el armamento y el equipo que había recibido en noviembre de $1911 .{ }^{32}$

En las anotaciones de Rosendo Pérez se encuentra que después de la muerte de Juárez Maza había "un clamor popular" por el desarme y encarcelamiento de los serranos por "los crímenes de Tlalixtac". ${ }^{33}$ Por su parte, Carlos Sánchez Silva afirma que en la prensa local pedían castigo contra los serranos protegidos de Juárez Maza y la desintegración de la primera compañía. Sabían que iban a ser castigados. ${ }^{34}$ Todas esas referencias abonan a la versión de la huida por la posible represalia hacia la primera compañía por el ataque a Tlalixtac. Aunque ésta no ha sido la única explicación del escape de León y sus milicianos. En menor medida circuló una historia distinta que se funde con el deceso del gobernador.

En la biografía de Juárez Maza, escrita por Esther Acevedo, encontramos que "la muerte del gobernador llegó de sorpresa". La viuda, María Klerian, le escribió al médico de la familia, J. Mayorales, porque tenía la sospecha de que habían envenenado a su esposo. Después de la inspección del cuerpo, el médico respondió a Klerian que no había encontrado ninguna sustancia. Las presiones del momento habían afectado al gobernador y le generaron un paro cardíaco. ${ }^{35}$ Ante el contundente veredicto

32 Onofre Jiménez, “Mi actuación revolucionaria en la Sierra Juárez de 1910 a 1920", manuscrito, s/f., p. 13.

33 Pérez García, Una revolución de ocho meses, p. 53.

34 SÁnchez Silva, "Conflicto intercomunal”, p. 117.

35 Acevedo, Benito Juárez Maza, 1852-1912, p. 185. 
del médico, la viuda no volvió a mencionar esa tentativa, pero la historia se divulgó de alguna manera como leyenda.

El señor Patricio Ramírez, un habitante de Teococuilco, entrevistado en los años ochenta, cuenta que don Benito fue envenenado cuando llegó del Palacio a su casa mientras leía el periódico. El asesinato había sido obra de "los licenciados, los políticos" que no aceptaban su gobierno. Por eso, Pedro León y el batallón no entregaron las armas al gobierno, agarraron camino a la Sierra y llegaron a la cabecera de Ixtlán, convocaron a los serranos en respuesta a lo sucedido. Hubo una junta y decidieron atacar. Ésta era la explicación para justificar el inicio de la revuelta, en palabras de Patricio Ramírez. A inicios de la década de 1990 todavía se contaba la historia del envenenamiento del hijo de Juárez en algunos pueblos. ${ }^{36}$

A esta historia podemos agregar un dato tomado de las memorias de Onofre Jiménez, quien dijo que Pedro León -ya en su calidad de prófugo- se dirigió a la cabecera del distrito y convocó a una junta. En la reunión, León expuso que los felicistas habían envenenado al señor Juárez. Por ello, la primera compañía había tomado las armas regaladas por el gobernador y pedían desconocer a las autoridades para "vengar la muerte de don Benito". ${ }^{37}$ Véase bien que la veracidad de los recuerdos

${ }^{36}$ Sobre la historia del envenenamiento de Juárez Maza está la entrevista a Patricio Ramírez, oriundo de Teococuilco de Marcos Pérez, realizada por Francisco José Ruiz Cervantes el 25 de abril de 1981. Este material forma parte de la serie Ruiz Cervantes, Documentos para la historia de la rebelión ixtepejana. En la época se difundió el rumor de que Juárez Maza cenó una noche antes de su muerte con un enviado de Madero. Eso generó suspicacias. En la niñez, la que escribe este texto escuchó la historia del envenenamiento del hijo de Juárez -quien "no era indio ni moreno como nosotros sino güero"- en voz de su abuela paterna, Esther J. Ruiz, en la cabecera municipal de San Pablo Macuiltianguis. No se mencionaba nada sobre la revuelta ni a Pedro León. 37 Onofre Jiménez, "Mi actuación revolucionaria en la Sierra Juárez de 1910 a 1920”, manuscrito, s/f, p. 13. 
de Jiménez puede ponerse en duda, pero se agrega este testimonio a la "versión de la venganza" porque coincide con otros registros.

Las evidencias de esta interpretación son muy débiles pues no se respalda en ninguna fuente documental, pero curiosamente se mantuvo en testimonios orales y se divulgó entre la gente de la región, ya sea para justificar el inicio de la revuelta y la acción de los miembros de la primera compañía o para encontrar una explicación al repentino fallecimiento del hijo de Juárez aquella noche del 20 de abril de 1912 por un infarto fulminante. Al parecer, más de una persona especuló sobre la extraña muerte de Benito Juárez Maza a los 59 años en un contexto político de agitación, inestabilidad social y disputa por el poder estatal.

La versión de "Pedro León vengador" se difundió medianamente, mientras que la versión de la furtiva huida de los responsables de los "crímenes de Tlalixtac" estuvo presente en algunos documentos y ciertas notas de la prensa de la época. Es preciso destacar que a los integrantes de la primera compañía se les denominó "desertores" porque estos hombres huyeron del cuartel provisional de la ciudad de Oaxaca rumbo a la Sierra Juárez con las armas que les había dado el gobernador para resguardarse. En este punto vemos que ya no se habla de los integrantes de la primera compañía enlistados al servicio del gobierno, sino que se refieren a un grupo de "desertores" que después se volvieron “rebeldes”. Veamos esa transformación.

\section{DE “DESERTOREs” A “REBELDEs”}

Después de la huida de la ciudad de Oaxaca, es difícil seguir el rastro de Pedro León y su compañía. Sin tener la fecha precisa, en los apuntes de Rosendo Pérez encontramos que, de los 100 integrantes de la primera compañía instalados en la ciudad de Oaxaca, 20 se quedaron en su puesto de guardias de la cárcel pública. Los otros 80 , junto con algunas mujeres, se refugiaron 
en Nexicho. El problema fue que esa agencia municipal (de donde era Pedro León) sólo contaba con 25 familias y no logró dar albergue a estos milicianos, quienes se dirigieron a la cabecera municipal de Ixtepeji. ${ }^{38}$

En la prensa local, además de los reportes sobre el funeral del gobernador, se encuentran algunas pistas de los integrantes de la primera compañía en su incursión a la Sierra Juárez. En el diario El Avance, el 1o de mayo, se publicó que los serranos habían atravesado algunos pueblos. Pedro León aún no tomaba posesión de Ixtlán como se hacía circular. ${ }^{39}$ Aunque no se decía más, al parecer dicha información se propagó y el gobierno tomó parte en el asunto.

Daniel García -el jefe político del distrito de Ixtlán, recién llegado- quedó a cargo de la persecución. Para el 9 de mayo de 1912, este hombre informaba al gobierno del estado que desde la localidad de Xía corrían noticias alarmantes de que se encontraban por las cercanías algunos individuos armados. Enseguida se trasladó al lugar, no encontró nada, pero se enteró de que estos hombres se estaban concentrando en Nexicho. ${ }^{40}$

Ante este nubarrón de rumores quedan algunos escritos que nos permiten seguir las huellas e intenciones de estos personajes. Gracias al hallazgo de un expediente judicial en donde se reunieron los escritos de Pedro León y Juan Martínez Carrasco se pueden conocer datos sobre la convocatoria a los pueblos de la Sierra Juárez en mayo de 1912, los planes y la ubicación de estos "desertores".

En un documento titulado "Pronunciamiento de Pedro León a los pueblos de la Sierra Juárez”, fechado el 15 de mayo de 1912, "el coronel” -véase que ya no era capitán- exponía que con la muerte de Juárez Maza terminaba su compromiso

38 PÉRez GARcía, Una revolución de ocho meses, p. 55.

39 BFFB, $M B C$, H, núm. 20, El Avance (1ํo mayo 1912), p. 1.

40 AGEO, Asuntos políticos, c. 1912, s/f: Comunicación de Daniel García, Ixtlán, 9 de mayo de 1912. Pérez García, Una revolución de ocho meses, p. 56. 
de servir al gobierno. Además, manifestaba que el gobierno interino les iba a quitar las armas que les "había obsequiado" Juárez Maza en pago de sus servicios. Para evitar el desarme, la primera compañía resolvía llevarse las armas no sólo para ellos sino para garantizar los derechos en el distrito. ${ }^{41}$

En la carta se denunciaba que el jefe político había pedido a otros pueblos su apoyo para quitarles su armamento y para aniquilarlos. Pero ellos, agregaba Pedro León, no eran ladrones ni asesinos ni estaban en contra del gobierno, sino que eran "leales defensores" de sus derechos. Esta aclaración no era simplemente para exponer su complicada situación ni tampoco se limitaba a hablar de la defensa de sus derechos sino también se hacía alusión de problemas sociales y económicos. Por eso, pedían unirse y convocaban a una junta general para ver la entrega de las armas y quedar "humillados y unidos en la oscuridad". ${ }^{2}$ Así concluía la carta que Pedro León dirigió a las cabeceras municipales de Jaltianguis, Analco, Atepec, Macuiltianguis, Comaltepec, Quiotepec, San Pedro (Yolox) y a las agencias de Luvina y La Soledad (Tectitlán). Al reverso de la hoja se encuentra el acuse de recibo en Jaltianguis el 16 de mayo y en Analco el día 17, pero no se sabe si efectivamente llegó a los demás municipios y cuál fue la posición de éstos.

$\mathrm{Al}$ parecer éste es el único documento en donde se remite a Juárez Maza y donde se convoca a todos en el distrito sin contemplar en la lista a Ixtlán. ¿Pero por qué no se dirigió a Ixtlán, que era la cabecera del distrito? ¿Por qué no se dirigía a sus antiguos compañeros del Batallón Sierra Juárez de la segunda y tercera compañía? En el listado de pueblos se encuentran algunos, pero había otros que no fueron considerados. No se descarta que se haya reproducido el mismo texto y enviado mediante cordillera hacia otros rumbos porque era una iniciativa general.

${ }_{41}$ AHCCJO, leg. 519, exp. 3, f. 64.

${ }^{42}$ AHCCJO, leg. 519, exp. 3, f. 64. 
A esta convocatoria se sumó el presidente de Ixtepeji, Juan Martínez Carrasco, de quien se sabe era "un ranchero sin tierras" que para esos meses de inicio de 1912 enfrentaba un problema de abigeato en la cabecera municipal de Ixtepeji. ${ }^{43}$ Desconocemos en qué momento se puso en contacto con Pedro León, pero posiblemente sus conflictos con el jefe político fueron un punto de coincidencia.

En esos días de mayo, Martínez Carrasco también escribió un mensaje en consonancia con la nota de León y agregaba datos nuevos. El 20 de mayo de 1912, desde la Villa de Ixtepeji, Martínez Carrasco solicitaba a los agentes y presidentes municipales les proveyeran de armas y los acompañaran a la compañía del batallón de Ixtepeji a Nexicho "ahora que esa villa resuelve poner un gobierno que nos considere el pago de doce centavos a la contribución federal”. El presidente municipal de Ixtepeji pedía que los acompañaran a quitar al "gobierno amagador" y a más tardar el 24 o 25 se unieran en Oaxaca para poner un nuevo gobernante. ${ }^{44}$ Con estos modestos propósitos, Martínez Carrasco se dirigía a los pueblos a que anteriormente había escrito Pedro León, aunque no hay registro de recepción en ningún municipio. Pero el levantamiento de armas no fue directo hacia la ciudad de Oaxaca, sino que primero fue a la cabecera del distrito.

De acuerdo con las declaraciones de algunos testigos y detenidos, este grupo armado tomó como punto de reunión la fábrica Xía y desde la noche del 21 de mayo y durante la madrugada del día 22 se dirigieron hacia Ixtlán. En el avance del contingente se fueron sumando más individuos; pasaron por Guelatao y llegaron a la entrada de la cabecera de Ixtlán. En ese lugar hicieron frente a un grupo de ixtlecos encabezados por el presidente municipal, Ezequiel Santillán. Este hombre declaró que en esa madrugada Pedro León dijo que se rebelaban contra el gobierno

43 Pérez García, Una revolución de ocho meses, p. 50.

44 AHCCJO, leg. 519, exp. 3, f. 66. 
y mencionó que postulaban para gobernador del estado al licenciado Arnulfo San-Germán, un político oaxaqueño liberal egresado del Instituto de Artes y Ciencias de Oaxaca que participó en la campaña de Benito Juárez Maza y posteriormente fue candidato a la gubernatura del estado apoyado por la fracción de los liberales. ${ }^{45}$ Después de esta declaración, los rebeldes entraron a la cabecera de Ixtlán ese 22 de mayo. ${ }^{46}$ Esta versión de la incursión, que se basa principalmente en testimonios coincidentes de Ezequiel Santillán y Onofre Jiménez, difiere un poco de las anotaciones de Rosendo Pérez García. Este profesor menciona que Pedro León llegó a la cabecera de Ixtlán a las nueve de la mañana porque había estado buscando aliados en Jaltianguis. ${ }^{47}$

No contamos con elementos para aclarar el momento de llegada de Pedro León a la cabecera distrital. Ambas versiones muestran nexos de León con otros personajes, ya sea San-Germán como la gente de Jaltianguis que en ese momento encabezaba Lauro García, uno de los integrantes de la primera compañía de Pedro León en Oaxaca. Como quiera que haya sido, el caso es que Pedro León no actuaba solo ni el asunto era exclusivamente labor de los ixtepejanos. Este último punto será analizado en las siguientes páginas. Pero lo cierto es que la incursión de Pedro León y Juan Martínez Carrasco fue a punta de balazos y matando a uno que otro poblador de la cabecera, como el alcalde primero Antonio Hernández.

\footnotetext{
45 La familia de San-Germán fue propietaria de una tienda de artículos de importación y de una imprenta. Este político fundó el diario El Ideal dirigido a las clases trabajadoras. En 1911 fue detenido por el delito de rebelión. Arellanes Meixueiro, Diccionario bistórico, p. 194. En días posteriores, el 28 de mayo, El Imparcial mencionaba que el levantamiento de Pedro León tenía como fin presionar para que se eligiera a San-Germán como gobernador. El Imparcial (28 mayo 1912), p. 1.

46 AHCCJO, leg. 519, exp. 3. ff. 4-6. Onofre Jiménez, "Mi actuación revolucionaria en la Sierra Juárez de 1910 a 1920”, manuscrito, s/f, p. 14.

47 Pérez García, Una revolución de ocho meses, pp. 59-61.
} 
Ya instalados en el palacio municipal, León y Martínez Carrasco aprisionaron al jefe político con su secretario -el profesor Alejandro C. Martínez, de Tepanzacoalco- y al escribiente Enrique Juárez Caballero, de Oaxaca, quienes fueron asesinados. Enseguida hicieron un escrito que daba reconocimiento a Miguel Hernández (aquel hombre acusado de rebelión en unión de León en 1910) como jefe político provisional para llevar los principios de la revolución. ${ }^{48}$ Pero la asignación de un nuevo jefe político no fue lo único que hicieron los autodenominados "jefes de la revolución" sino que también firmaron un manifiesto.

Según la narración de Rosendo Pérez, cuando Pedro León estaba en la cabecera distrital expuso ante la gente en el salón municipal que se había levantado en armas contra el gobierno "porque deseaba liberar al pueblo de tanta injusticia e inequidad". Acto seguido, el "jefe revolucionario" proclamó que sólo se pagarían 12 centavos de capitación en vez de 22 y que se suspendería la Ley de Hacienda. Además, León agregaba que marcharían a Oaxaca directamente para "tomarla". Ante esto, a la concurrencia sólo le quedó aplaudir y gritar: “ ¡Viva la Sierra Juárez! ¡Viva don Pedro León! ¡Viva el real de capitación! ¡Mueran los 22 centavos, la ley de hacienda y el gobernador del estado!". ${ }^{49}$

Probablemente esta escena goce de ciertos adornos narrativos para engrandecerla, pero sí coincide -en algunos puntoscon un documento hallado en los expedientes judiciales que lleva como título "Manifiesto de la Sierra Juárez a la nación", firmado por el "jefe del movimiento insurreccional en el estado”, el general Pedro León, el segundo jefe Juan Martínez Carrasco, el capitán José Cruz Castellanos, en el distrito de Ixtlán el 22 de mayo de 1912.50

\footnotetext{
48 AHCCJO, leg. 519, exp. 3, f. 71.

49 Pérez García, Una revolución de ocho meses, pp. 59-61.

50 AHCCJO, leg. 519, exp. 3, f. 70.
} 
En el primer párrafo del documento se encuentra una convocatoria formal de inicio de la guerra. El lenguaje solemne hacía alusión al pasado glorioso de los serranos en el campo de combate y con un furor patriótico al estilo decimonónico se hablaba de libertad y valentía. En el escrito, los "jefes revolucionarios" explicaban que el "error" había sido la exigencia de "la contribución sobre bienes raíces y la onerosa contribución o cuota personal" de los gobiernos pasados. Esa ley era considerada como "una pesadilla para los ciudadanos" pero la Sierra Juárez fue la primera en dar el llamado de alerta a la nación entera; sin embargo, no quisieron derramar sangre hermana ni "teñir de púrpura el suelo patrio" y dejaron en el olvido su bélica actitud. ${ }^{11}$

Ante las circunstancias de ese momento, los serranos volvían a dar el grito de alerta. Por ello, "excitaban" al patriotismo y la voluntad del pueblo mexicano para secundar su ideal de "supresión de las contribuciones sobre bienes y raíces y disminución de las cuotas personales". Hablaban de la uniformidad de ideales para defenderlos por medio de la razón y la justicia empuñando "el arma de la palabra y de la bayoneta". Así se lograría la felicidad y el bien común. ${ }^{52}$

Después de este manifiesto y la invasión a la cabecera de Ixtlán del 22 de mayo, a las pocas horas Pedro León salió con algunas tropas hacia el paraje de La Cumbre para seguir con el proyecto de atacar a la ciudad de Oaxaca. Previo a esta acción, nuevamente elaboraron un documento el 26 de mayo. En ese escrito se hacía una recapitulación de temas ya mencionados en el manifiesto del día 22, pero se agregaban otros elementos que comentamos al inicio de este escrito. ${ }^{53}$ Hasta este momento, podemos ver que ya había un plan político definido y la amenaza de atacar a la capital del estado.

51 AHCCJO, leg. 519, exp. 3, f. 70.

52 AHCCJO, leg. 519, exp. 3, f. 70.

53 AHCCJO, leg. 519, exp. 3, f. 68. 


\section{LOS “REVOLUCIONARIOS” EN ACCIÓN}

Ya habíamos mencionado que en la carta de Juan Martínez Carrasco del 20 de mayo se había previsto un ataque a la ciudad de Oaxaca los días 25 y 26. Aunque no fue en esa fecha exacta, este grupo intentó invadir la capital el día 27. Los rumores sobre el avance de los serranos se cristalizaron en acciones concretas de cortes de agua y asedio en los alrededores de la ciudad, que describimos al inicio de este escrito. Al parecer, la llegada de los serranos a la ciudad y la falta de tropa inquietaron a algunos sectores de Oaxaca y de fuera. En la historiografía de la revolución se hallan referencias de que el grito de " $i A i$ vienen los serranos!” causaba terror y psicosis en la ciudad en esos días de mayo y junio. No era la primera vez que desde la Sierra Juárez intentaban bajar a la ciudad de Oaxaca y cortar el agua. Eso había sucedido en $1876 .{ }^{54}$ Pero la proeza lograda en el pasado se veía distante para 1912.

En los hechos, los serranos no lograron entrar a la ciudad en pocas horas. Por el contrario, el combate con los rurales, el $12^{\circ}$ regimiento, los auxiliares y los voluntarios se dio durante horas con ataques esporádicos. Es extraño ver que a pesar del alargamiento de la confrontación y de tener un escenario menos ventajoso, Pedro León y Martínez Carrasco insistieran y mandaran una carta a Alberto Montiel, quien era el gobernador interino, para pedirle la plaza el 29 de mayo. En ese documento, "el jefe del Ejército Revolucionario de la Sierra Juárez” desconocía al gobierno de Francisco I. Madero y se afiliaba al movimiento revolucionario que acaudillaba Pascual Orozco..$^{55}$

Enseguida, León pedía la plaza para que sus fuerzas tomaran posesión y así se asegurase el triunfo completo "de los

${ }^{54}$ Ruiz Cervantes, La revolución en Oaxaca, pp. 36-57. Kearny, Los vientos de Ixtepeji, p. 57.

${ }^{55}$ AHCCJO, leg. 517, exp. 9, f. 15. 
redentores principios" del Plan de San Luis reformado en Tacubaya. En tono benévolo le decía a Montiel que meditara bien la situación para evitarle grandes males a la capital y para no dar lugar a una desastrosa matanza entre hermanos. Los "revolucionarios" apelaban al patriotismo del gobernador y reclamaban unión y confraternidad en tiempos que "la Patria [era] traicionada por hombres ambiciosos y perversos" ${ }^{56}$

En la misiva explicaban que si la plaza se rendía, las fuerzas serranas respetarían las vidas de nacionales y extranjeros, con garantías especiales para los obreros, los artesanos, los agricultores y los comerciantes que no se opusieran a sus planes revolucionarios. Lo raro es que no aclaraban cuáles eran esos planes revolucionarios ni qué harían después de "tomar esa Capital a sangre y fuego si fuese necesario". ${ }^{57}$

Por desgracia para Pedro León, tan buena retórica no estuvo acompañada de acciones armadas contundentes. Los serranos no consiguieron hacer retroceder a las tropas de rurales ni al $12^{\circ}$ regimiento ni a la compañía de auxiliares. " $\mathrm{Ni}$ a sangre ni a fuego" lograron ocupar la plaza de la ciudad de Oaxaca. Por el contrario, los serranos estuvieron disparando escondidos desde los peñascos y poco después tuvieron que huir hacia la cumbre de El Estudiante y luego rumbo al camino nacional para refugiarse, ${ }^{58}$ buscar aliados y posiblemente armas, municiones, alimentos y dinero después de cuatro días de combate.

A pesar del intento fallido, el 1o de junio de 1912, León y Martínez Carrasco, decían tener el honor de remitir el plan proclamado en la Villa de Ixtepeji a los 16 pueblos del distrito de Ixtlán y expedían la circular a las autoridades municipales para que quedaran enterados de no pagar por más tiempo más de 12 centavos de impuesto personal de capitación. ${ }^{59}$ Aquí podemos

\footnotetext{
${ }^{56}$ AHCCJO, leg. 517, exp. 9, f. 15.

57 AHCCJO, leg. 517, exp. 9, f. 15.

58 El Imparcial (30 mayo 1912), p. 8.

59 AHCCJO, leg. 519, exp. 3, f. 73.
} 
advertir que el tema de la capitación -mencionado en los escritos del 20, 22 y 26 de mayo- siguió vigente en las demandas de este grupo. Por otra parte, a este plan se le agregaba que se había proclamado "la Villa de Ixtepeji".

Ese mismo día, 1 de junio, estos dos dirigentes se comunicaron con Miguel Hernández, el jefe político provisional, mediante una carta que dejaba ver una gama de asuntos pendientes y por atender entre ellos. Conviene explicar en este punto que mientras León y Carrasco fueron a atacar la ciudad de Oaxaca, Hernández se quedó en la cabecera de Ixtlán ocupando su nuevo cargo. Considérese que Miguel Hernández no era ixtepejano sino ixtleco y, como se mencionó páginas arriba, participó en la intentona de rebelión de 1910.

No sabemos si se encontraron con Hernández en Xía, pero si revisamos con detenimiento la carta a este "jefe político provisional” vemos peticiones de su apoyo con más elementos para la guerra. De ello puede inferirse que probablemente se quedaron con pocos combatientes y les faltó apoyo de otros pueblos (eso incluye dinero y armas). Por esa razón, los cabecillas del levantamiento convocaban a Miguel Hernández a "limar asperezas" y olvidar "rencores". Tal vez buscaban aliados y querían mostrar que no estaban contra la gente del distrito, por eso pedían el restablecimiento del libre tránsito de la Sierra a Oaxaca tanto para los pueblos como los industriales. El sentido de no afectar el orden se reafirma con la petición de que se asegurara el buen curso de las actividades de las escuelas. ${ }^{60}$ No se conoce la respuesta de Miguel Hernández, pero esta carta aporta elementos para reflexionar sobre la tensa relación entre los "rebeldes", sus posibles desavenencias y alianzas frágiles. No se descarta que para fines de mayo de 1912 el levantamiento de Pedro León no contara con tantos adherentes y buscara respaldo.

60 AHCCJO, leg. 519, exp. 3, f. 74. 
Imagen 1

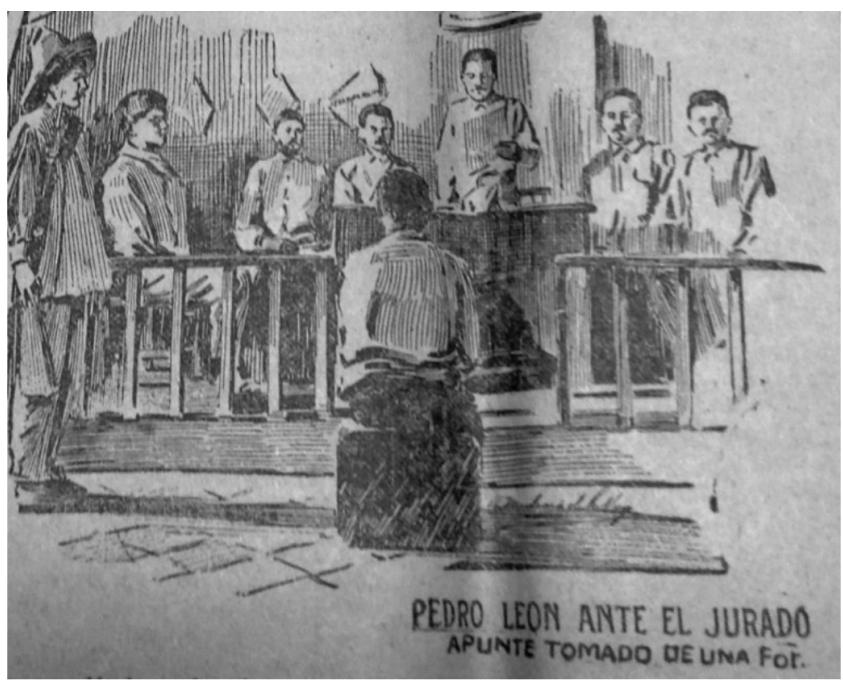

“El juicio de Pedro León”, El Imparcial (19 jun. 1912), “El de los crímenes y toda 'la bola' es ese diablo de Carrasco”, p. 2a. Humberto L. Strauss.

Lo anterior se puede corroborar con el último escrito de Pedro León seis días después. En una carta del 7 de junio de 1912, desde el municipio de Jaltianguis, el jefe del Ejército Libertador Sierra Juárez escribía un pequeño texto en donde sin más preámbulos informaba que salía rumbo al norte y pedía se le proporcionaran elementos de vida y auxilio con otros que pudiera necesitar cuando pasara por algunos pueblos. León decía que iba en "son de paz" y que le dieran tránsito libre en los municipios de Analco, Atepec, Macuiltianguis, Comaltepec, Yolox y Quiotepec. De los pueblos nombrados sólo el presidente municipal de Analco, Antonio Manzano, daba acuse de recibido. Quizá este movimiento de Pedro León era para acercarse a la Chinantla con el propósito de entrar en contacto con el dirigente de Quiotepec, Pedro Castillo, con quien se le había relacionado 


\section{Imagen 2}

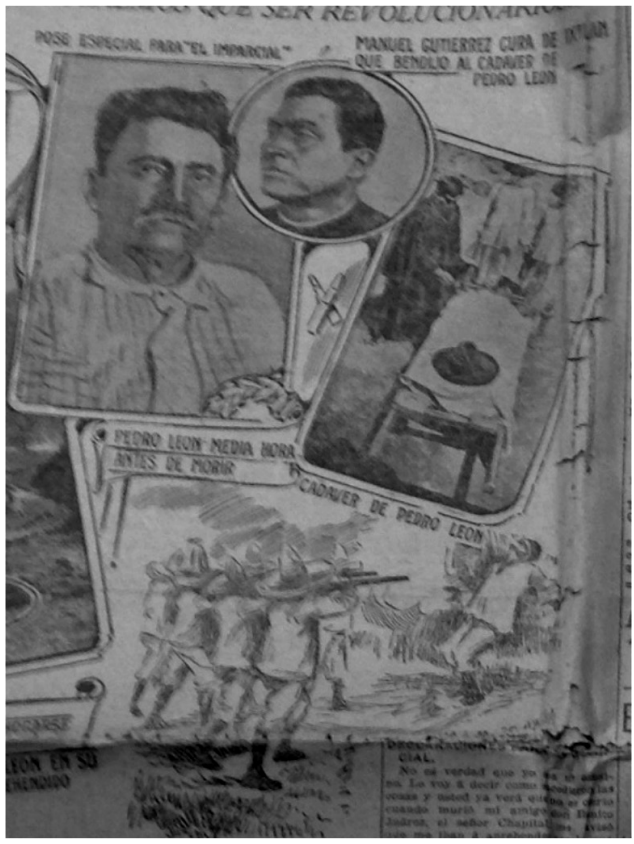

Imagen de Pedro León. Fusilamiento y cadáver, El Imparcial (19 jun. 1912), “El de los crímenes y toda 'la bola' es ese diablo de Carrasco”, p. 1ª Humberto L. Strauss.

en 1910. Desafortunadamente, Pedro León no logró llegar ni a la mitad del camino. A su paso por el pueblo de Jaltianguis, el jefe revolucionario fue atrapado y entregado a sus enemigos ixtlecos el 9 de junio. ${ }^{61}$

Por esos días, el caudillo serrano Guillermo Meixueiro regresó a Ixtlán y con Ezequiel Santillán y Onofre Jiménez retomaron el mando político en la cabecera municipal. Juntos

61 AHSDN, XI/481.5/207, ff. 577. AHCCJO, leg. 519, exp. 3, f. 75. PÉrez GARcía, Una revolución de ocho meses, p. 40. 
encarcelaron a Miguel Hernández, que dirigía a un grupo de 39 hombres que habían asediado a los pueblos por esos días. Pedro León estuvo preso por unas horas y después lo fusilaron en la pared de la iglesia de San Francisco. Las imágenes que se presentan a continuación, tomadas de El Imparcial, muestran a Pedro León en su juicio y fusilamiento. Con este acontecimiento se cierra una primera etapa del levantamiento armado en donde se observa la transformación del grupo de desertores de la primera compañía en revolucionarios del Ejército Libertador de la Sierra Juárez.

\section{ALEGORÍA REVOLUCIONARIA REVISADA}

En diversos trabajos de historia social generalmente se habla de la dificultad de estudiar a los grupos populares o subalternos, pues no dejan registro escrito o es complicado encontrar otras evidencias de sus ideas y planes. De acuerdo con esto, las muestras disruptivas y esporádicas son momentos únicos de análisis para el estudioso del tema. En el caso de la Sierra Juárez encontramos una serie de documentos que, en términos de la historia social, muestran esa parte del "ideario", "imaginario rebelde" o "ámbito autónomo subalterno". ${ }^{62}$

Si seguimos al pie de la letra estas proclamas, podríamos pensar en las distintas fases de un movimiento que va de la disidencia hasta la acción revolucionaria. Diversos factores pueden afianzar esta idea. En la desintegración del régimen político porfiriano, numerosos grupos saltaron a la palestra principal del escenario nacional para hacer públicas sus demandas. La historiografía del periodo ha documentado la participación popular que confluyó en lo que se conoce como "ejércitos campesinos".

Las menciones de la "revuelta ixtepejana" de los años ochenta se sumergieron en la retórica de la prensa de la época y siguieron

${ }_{62}$ GuHA, Las voces de la historia. 
los registros de los combates por parte del ejército y rurales sin vacilar en las denominaciones. En la lógica del momento "la rebelión ixtepejana" se entendió como uno de los tantos movimientos revolucionarios que se dieron en el país. La denominación de "revolucionario" fue general e imprecisa, pero sirvió como un recurso útil para englobar aquello que ocurría en lugares apartados y disímiles.

Para el análisis que aquí se presenta, hay una serie de cartas que nos revelan, día a día, cómo se fue dando la organización de un grupo armado, sus demandas y su plan de acción. Sin dudar de que este tipo de documentos presenten partes no conocidas del "imaginario popular", tampoco podemos dar por cierto todo aquello que dicen estos dirigentes. Si estos escritos se revisan a contrapelo, el resultado puede ser diferente. Por ello conviene reflexionar de nuevo.

De inicio, se retoman las cartas del 15 de mayo escrita por Pedro León y la del 20 de mayo escrita por Juan Martínez Carrasco. La información que nos proporcionan estas misivas nos ayuda a vislumbrar algunas etapas organizativas de estos "desertores" que se fueron inclinando hacia el levantamiento armado. En la carta de Pedro León se puede apreciar la construcción de un discurso que apelaba a la identidad serrana juarista, la defensa del territorio ante posibles amenazas y las condiciones de la efervescencia social del momento.

En esta primera carta del 15 de mayo, Pedro León no mencionaba nada del supuesto envenenamiento del gobernador, así como ninguna clase de "venganza" por su asesinato. Simplemente, León exponía que habían escapado para evitar el desarme. Pero sí agregaba el tema relevante de protegerse de la inseguridad en los caminos, en especial, por la amenaza de los pobladores de Tlalixtac. Claro que no decía nada de la confrontación de diciembre de 1911 en ese lugar. Si se sigue el texto, observamos que esta carta era una convocatoria de "unidad" (amoldada a los intereses del dirigente de la primera compañía) 
ante la crisis. Según el escrito, Pedro León buscaba que otros pobladores de la Sierra lo apoyaran y recurría a un rasgo de singularidad de la región: la herencia del indio de Guelatao.

Pero con ese escrito destacamos algunos otros detalles. Uno de ellos era el inicio de la transformación del personaje de Pedro León: dejaba de ser el capitán de la compañía de desertores y se convertía en el coronel del grupo rebelde que daba sus primeros llamados desde el campamento en el paraje La Cumbre. Ésta era una invitación inicial a tomar las armas con el respaldo de los pueblos de todo el distrito en una junta general.

El tema de la junta general, o por decirlo, este primer llamado de unidad de Pedro León, coincide con un dato tomado de las memorias de Onofre Jiménez. Ya se mencionó en un apartado anterior que Jiménez aseguró que, al llegar a la Sierra Juárez, Pedro León convocó a una reunión en la cabecera de Ixtlán para que tras la muerte del gobernador todos tomaran las armas. Pero en la cabecera del distrito frenaron esta iniciativa. Ante esto, León "se declaró enemigo de la cabecera y sus autoridades" y se fue a Ixtepeji, donde sí lo secundaban. ${ }^{63}$ No hay fecha de este acontecimiento, aunque probablemente fue entre el $15 \mathrm{y}$ el 19 de mayo. Una explicación posible es que en este momento pudo haberse dado el punto de ruptura entre Pedro León y los dirigentes de la segunda compañía abanderada por Ixtlán. Al parecer, el argumento de la defensa del distrito no fue convincente para los ixtlecos, pero eso no evitó que encontrara aliados y uno de ellos fue el presidente municipal de Ixtepeji.

El fracaso en la junta general que menciona Onofre Jiménez en sus memorias podría ser explicado por algunos factores que se relacionan. El primero pudo haber sido la rivalidad entre dirigentes, que posiblemente se había dado desde las elecciones de 1910 -por no irnos más atrás- y las diferencias entre capitanes

63 Onofre Jiménez, "Mi actuación revolucionaria en la Sierra Juárez de 1910 a 1920”, manuscrito, s/f, p. 13. 
del Batallón Sierra Juárez desde noviembre de 1911. Es probable que en la ciudad de Oaxaca, durante la concentración del Batallón Sierra Juárez, se engendraran algunos desacuerdos entre capitanes y eso provocó la desintegración de dicho batallón y el rechazo hacia Pedro León.

Un segundo factor, relacionado con el primero, tiene que ver con las percepciones que se tenían de Pedro León. Según Onofre Jiménez, León era poco conocido en la Sierra porque había crecido en Villa Alta bajo el auspicio del comerciante y político Miguel Castro. ${ }^{64}$ Probablemente, Pedro León no tenía la suficiente legitimidad ante los dirigentes de Ixtlán ni tampoco compartían los mismos intereses. Otro dato que no hay que dejar de lado es que León pertenecía a una agencia que intentaba abanderar a la gente de la cabecera del distrito. Difícilmente los ixtlecos aceptarían que el líder de una agencia fuera el principal dirigente de un levantamiento armado, y menos si se considera que la agencia era de ese enemigo histórico que fue Ixtepeji. Viendo estos elementos no es extraño encontrar que en Ixtlán no secundaran a Pedro León.

Esta respuesta negativa no provocó el cese de los proyectos de la tropa de desertores puesto que encontraron aliados de quienes recibieron apoyo. En ese marco se ubica la carta del 20 de mayo de 1912 de Juan Martínez Carrasco que da la pauta al segundo momento. En este documento, más breve e informal, ya se daba por entendido el levantamiento armado y se buscaba el apoyo de algunos agentes y presidentes municipales. Las menciones a Juárez Maza ya no se encuentran ni tampoco se habla del asunto de las armas. Atrás había quedado la "primera compañía de desertores" y en su lugar se encontraba "la compañía del batallón" que ya se empezaba a movilizar.

${ }^{64}$ Miguel Castro no era cualquier minero y fue mentor de Fidencio Hernández y Francisco Meixueiro. Posiblemente Pedro León conocía bien a estos dos y su influencia fue menor en la Sierra. Incluso se podría especular que León era el "ala progresista de este grupo". 
En el escrito del presidente de Ixtepeji observamos la estrategia a seguir y el plan de acción con la tentativa de ir a Oaxaca para el 25 o 26 y poner un nuevo gobernador. Pero esta carta también dejaba ver que los rebeldes tenían una demanda: la disminución de la capitación. Nuevamente esta información coincide con las memorias de Jiménez, quien reportó que en esos días Pedro León invitó a los demás pueblos a que lo secundaran y les prometió la reducción del impuesto a la capitación a 12 centavos. ${ }^{65}$ En el manifiesto del 22 de mayo, cuando realizaron su ataque previo a la capital del estado, y en el plan del 26 de mayo, se volvía a hablar de la capitación.

Llegado a este punto no se puede dejar de lado que quizá el problema de la capitación fue relevante en esta región y nos introduce a un tema fiscal. La capitación era un tipo de impuesto que se comenzó a utilizar en el periodo independiente (a partir de 1842) con fines de recaudación y que tuvo algunos rasgos similares al tributo colonial, pero con la diferencia de que no se dirigía especialmente a la población indígena sino también incluyó a los mestizos. ${ }^{66}$ Los especialistas en el tema mencionan el caso singular de Oaxaca porque hubo una constante en el pago de dicho impuesto. Parecía que se mantenía una larga tradición tributaria. El pago indígena constituyó un ingreso sustancioso para el estado hasta el año de 1915, cuando se decreta la abolición de la capitación. ${ }^{67}$

Para los fines de este escrito, no contamos con la información de la tesorería del estado de Oaxaca ni con elementos para

${ }^{65}$ Onofre Jiménez pone énfasis en que esos recorridos de Pedro León estuvieron acompañados de robos y saqueos contra las personas que se oponían a cooperar. Onofre Jiménez, "Mi actuación revolucionaria en la Sierra Juárez de 1910 a 1920”, manuscrito, s/f, pp. 13-14.

${ }^{66}$ La importancia de la contribución indígena proviene del tributo colonial y se mantuvo en el siglo xix. Sánchez Silva, Indios, comerciantes y burocracia, p. 114.

67 En relación con este gravamen véase Serrano, "Contribuciones directas y reformas fiscales". MenEgus, "La transformación de la propiedad”. 
corroborar si el cobro del impuesto de capitación o el monto que se recaudaba generaron problemas. Se desconoce si efectivamente hubo una disminución del pago de la capitación o algunas variaciones. Salvo la demanda expuesta por estos dirigentes, no hay indicios de conflictos en esta región a fines del siglo XIX e inicios del xx. Lo inquietante del pronunciamiento de Pedro León y Martínez Carrasco fue que no pedían la eliminación del impuesto sino su disminución. ${ }^{68}$

Por lo visto, no estaban en contra del impuesto, sino que les parecía oneroso el costo. Con relación a esto, conviene mencionar que en 1910, Pedro León y Miguel Hernández tomaron las armas y robaron los fondos de capitación en algunos pueblos de la zona de la Chinantla, pero no lograron convocar a más pobladores. Para 1912, Pedro León y sus aliados prefirieron enarbolar la demanda de la disminución de la capitación. Hasta el momento no se han encontrado casos similares en Oaxaca.

En el universo de planes políticos de 1912 si hay alguno que pueda acercarse medianamente al tema abordado por los serranos se podría citar el Plan de Peribán de Ramos, Michoacán, del 29 de enero de 1912, donde se habla de la suspensión de todos los impuestos. ${ }^{69}$ De ahí no hay menciones en el caso de los planes y los manifiestos en otras regiones del país, pero tampoco se deja de lado que si en Peribán se referían a todos los impuestos, en el caso de la Sierra Juárez se trataba de un impuesto con características particulares. Este intrigante caso de la capitación queda abierto y pendiente a responder. No se puede descartar que en un futuro se encuentren elementos para hallar algunas causas fiscales que motivaran a los habitantes de esta región para tomar las armas, pero por el momento no se puede sostener eso.

${ }^{68}$ Queda pendiente hacer un análisis de los registros de la Tesorería del Estado de Oaxaca para ver qué había pasado con el cobro de la capitación en el siglo xx, para tener mayores elementos analíticos.

${ }^{69}$ Iglesias González, Planes políticos, proclamas, pp. 635-636. 
Sin tener certeza de que la capitación fuera el elemento más apremiante y fuente de problemas en la Sierra Juárez, no se descarta la posibilidad de que estos dirigentes valoraran la importancia del ingreso y vieran provechoso el cobro, pero con fines más prácticos y en su beneficio. Esto se relaciona al siguiente paso dado: la invasión a la cabecera del distrito y el reemplazo del jefe político. Pese a que aún no se alcanza a distinguir en qué grado se había planeado esta incursión a la cabecera de Ixtlán, ya que en los documentos de los dos dirigentes no encontramos señales de esta orden, no sería extraño que antes de avanzar a Oaxaca se movilizaran para eliminar a sus enemigos y juntar fuerzas con sus aliados.

Con el asalto a la cabecera del distrito encontramos otro momento de inflexión de los "rebeldes" porque se dieron a conocer dos documentos: el manifiesto a la nación del 22 de mayo y el plan político del 26 del mismo mes. Estos documentos, descritos anteriormente, pueden ser vistos como estandartes del "movimiento revolucionario". Por obvias razones, aquellos que habían sido guardianes del gobierno de Benito Juárez Maza y que se habían convertido en "desertores" mostraban que no eran unos simples "rebeldes" sino que con sus manifiestos políticos se convertían en todos unos "revolucionarios".

Como puede advertirse, en el documento del 22 de mayo se encuentra un discurso bien delineado con una problemática clara y dirigido a un público que sobrepasaba las fronteras del distrito de Ixtlán, en donde se hablaba de la revolución y la justicia. Había algunas frases como "el imperio del proletarismo" y en una nota final decían que se adherían "al movimiento general de la República basado en el plan de Ayala Estado de Morelos modificado el 25 de noviembre de 1911".70

La suma de referencias de este escrito muestra una diversidad de temas; no obstante, algo curioso es la adhesión al Plan

70 AHCCJO, leg. 519, exp. 3, f. 70. 
de Ayala. Una lectura superficial podría inferir que los serranos estaban ligados con los zapatistas o que Pedro León tenía nexos con algún dirigente de Morelos, pero una reflexión un poco más profunda podría darnos otra respuesta. En las investigaciones sobre la "revuelta ixtepejana" no hay referencias al documento anteriormente descrito ni tampoco se han hecho asociaciones entre los serranos y los zapatistas para el año de 1912. No se descarta que en Oaxaca hubiera grupos vinculados con el zapatismo, como el de Ángel Barrios de Cuicatlán, o los acercamientos de rebeldes zapatistas en los límites de Puebla y Oaxaca, pero en el caso de la Sierra Juárez no se encuentran evidencias de tratos con los "rebeldes del sur".

Recurriendo a la lógica, tal vez los serranos podrían coincidir con los pueblos de Morelos en el interés de salvaguardar su territorio y a sus poblaciones ante los enemigos de fuera. Pero si revisamos el Plan de Ayala del 21 de noviembre de 1911, mencionado en el documento, además de desconocer al gobierno de Francisco I. Madero, el eje principal fue la restitución de las tierras a los pueblos. ${ }^{71}$ Lo singular es que en el caso de la Sierra Juárez no se dio un movimiento generalizado que pidiera tierras. Hasta el momento no se encuentra alguna referencia al despojo de tierras ni la demanda de restitución en los pronunciamientos del grupo encabezado por Pedro León y Juan Martínez Carrasco. Esto no quiere decir que no existieran conflictos por límites territoriales en la región, ni que no hubiera algunos pobladores litigando por sus terrenos (de eso hay una amplia documentación del siglo XIX). Lo que nos interesa destacar es que no había una demanda colectiva ni generalizada por la restitución de tierras como la de los zapatistas.

Este tema nos remite a una discusión que se dio hace algunas décadas en la que se habló de los campesinos oaxaqueños y los

71 Ávila, Los orígenes del zapatismo, pp. 200-210. Pineda Gomez, A cien años del Plan de Ayala. 
zapatistas. En los años setenta y ochenta, en la historiografía sobre la Revolución se vertió un debate interesante sobre esta situación. Ronald Waterbury expone la tesis de que mientras los campesinos de Morelos lucharon y murieron para cambiar, los campesinos oaxaqueños defendieron el statu quo. El autor explica que la situación agraria fue muy distinta en estos dos lugares. En Morelos hubo un alto porcentaje de concentración de la tenencia de la tierra en manos de las haciendas, mientras que en Oaxaca fue menor. En el caso de los "campesinos de las montañas”, del distrito de Ixtlán, Waterbury ubica que el desarrollo de la minería creó un espacio económico mediano caracterizado por relaciones paternalistas con los dueños de las minas. ${ }^{72}$

La imagen de los "no revolucionarios" en Oaxaca de Waterbury o ese "mito del campesino pasivo" fueron rebatidos en sus estudios regionales de los años ochenta por los historiadores oaxaqueños Francie Chassen-López y Francisco José Ruiz Cervantes, en donde se veía que no hubo pasividad ya que los campesinos oaxaqueños también tomaron las armas.

Al revisar esta polémica, conviene retomar algunas partes de cada postura. Por un lado, algo innegable para el caso de la Sierra Juárez es que efectivamente no hubo demandas agrarias para el periodo revolucionario. Eso se relaciona con la situación geográfica de la región, menos comunicada y accesible por su orografía. También tiene que ver el desarrollo de actividades ligadas a la minería, a la agricultura tradicional de subsistencia y a la fábrica textil. Esta variedad en las actividades incidía en que no todos los pobladores fueran campesinos ni todos se dedicaran a trabajar la tierra. Al respecto, vale aclarar que esta heterogeneidad no es exclusiva de la Sierra Juárez ni de Oaxaca. De hecho, tal como

72 Waterbury hace una comparación sobre las condiciones previas a la Revolución en los dos estados. En especial destaca la expansión de las haciendas en Morelos a diferencia de lo que sucedió en los Valles de Oaxaca. Además, considera la población indígena y la explotación de la grana cochinilla en Oaxaca. Waterbury, "Non-Revolutionary Paesants", pp. 410-442. 
ya lo ha propuesto Romana Falcón, sería conveniente revisar el término de "campesino", que si bien ha sido útil nos lleva por terrenos poco precisos. ${ }^{73}$ Otro punto significativo es que tampoco había grandes hacendados. De hecho, hubo poca expansión de la hacienda en esa región. Así que el binomio campesinohacendado no puede aplicarse para nuestro caso.

Ahora bien, el hecho de que no estuviera presente esta clase de relación no implica que en ese lugar reinaran la paz y la tranquilidad. Ni tampoco que estos serranos quisieran conservar su statu quo. Estos pobladores no eran pasivos y estaban inmersos en conflictos, pero sería complicado aseverar que eran todos unos revolucionarios. Si efectivamente los pobladores de la Sierra Juárez tomaron las armas, quizá no haya sido con el objetivo de transformar el orden sociopolítico preexistente sino para sobrevivir, defender lo poco que tenían o resguardar a sus familias.

Para 1912, se puede apreciar que tal vez la retórica de Pedro León y Juan Martínez Carrasco fue radical y compartida por cierto número de adherentes, pero sin un respaldo mayor. Si consideramos que sabían bien de la importancia del "arma de la palabra”, como se decía en el manifiesto político, la adhesión al Plan de Ayala pudo haber sido estratégica, como un agregado al final para no dejar de mostrar que se respaldaban en un movimiento rebelde con un plan político definido que buscaba aliados para levantarse en armas. Gracias a este tipo de estrategia narrativa, el grupo encabezado por León y Carrasco aparecía como un "movimiento insurreccional” que tenía al frente al "General” Pedro León.

A los pocos días, un nuevo documento político se dio a conocer, en que se resumían las ideas y demandas principales

${ }^{73}$ Este tema ha sido desarrollado recientemente por Romana Falcón para el Estado de México y se podría aplicar para otros estados y regiones. Falcón, Eljefe político, pp. 31-34. 
del grupo disidente. Con ello, Pedro León y Juan Martínez Carrasco dieron un paso más para conformar la imagen de un movimiento revolucionario a la par de otros. Esto se muestra en el plan político del 26 de mayo, citado al inicio de este texto. Con el desconocimiento del gobierno de Francisco I. Madero, la tropa de Pedro León se sumaba a la posición de otros grupos rebeldes opositores al gobierno de Madero que le reclamaron al presidente la "traición de los principios de la revolución" por los pactos con Porfirio Díaz en Ciudad Juárez y el incumplimiento de las demandas sociales. Así, Pedro León y Juan Martínez Carrasco seguían los pasos de los hermanos Vázquez Gómez con el Plan de Tacubaya, Orozco con el Plan de la Empacadora y Zapata con el Plan de Ayala.

La referencia al Plan de Tacubaya mencionado en el segundo punto llama la atención. En el documento, los jefes revolucionarios ratificaban el Plan de San Luis reformado en Tacubaya y resolvían "no pagar por más tiempo más de doce centavos del impuesto personal de capitación”. Lo extraño es que en el citado texto de Tacubaya no había referencia a ningún tema fiscal. Si revisamos este plan del 31 de octubre de 1911 encontramos que se presentan demandas políticas como la anulación de las elecciones, la disolución de las cámaras, la presidencia de Emilio Vázquez Gómez y la reivindicación de "la resolución del conflicto agrario". ${ }^{74}$ Este punto se relaciona con el Plan de Ayala, pero como ya se ha dicho, ésta no era una demanda en la Sierra Juárez.

Siguiendo con el plan, lo que nos interesa es la referencia a Pascual Orozco que fue motivo de suspicacias. Incluso, en ese periodo las alusiones a Orozco influyeron para que el ixtleco Amado Pérez denominara a la rebelión de mayo de 1912 como "orozquista-ixtepejana". ${ }^{75}$ Puede ser que la

74 Iglesias González, Planes políticos, proclamas, p. 626.

75 Amado Pérez, "Apuntes sobre la revuelta orozquista-serrana-ixtepejana de 1912”, manuscrito, s/f. 
referencia a Orozco no fuera del todo descabellada puesto que fue el general más prestigioso de la revolución maderista y había sido reconocido como dirigente principal en el Plan de Ayala, pero sería complicado asociar a Pedro León y Juan Martínez Carrasco con Orozco. Al menos no hay pruebas que soporten tal relación o nexo.

En una revisión del Plan de la Empacadora, elaborado en el cuartel general de Chihuahua el 25 de marzo de 1912, encontramos que se desconocía a Madero como presidente, pero se mantenían los otros poderes de la nación. De los 35 puntos que tocaba ese plan se contemplaba una reforma de la organización y estructura del gobierno nacional con menciones a la defensa del municipio libre. ${ }^{76} \mathrm{Sin}$ embargo, las peticiones y el lenguaje de este plan eran muy distintos al plan de León y Martínez Carrasco. La coincidencia era únicamente en el desconocimiento del presidente, pero no más que eso.

Cabe la posibilidad de que la referencia a Orozco, a la par que su anterior adhesión al Plan de Ayala, se hiciera más con fines políticos que por simpatías o afinidades. En ese sentido el documento del 26 de mayo se entiende como un recurso para afianzar un discurso revolucionario en búsqueda de legitimidad hacia el exterior como un grupo que desconocía a Madero y se enfrentaba al gobierno del estado. Paralelamente también aludía a la legitimidad interna para presentarse ante los municipios de la Sierra como abanderados de una "causa justa" como la reducción del pago de la capitación.

Quizá con este plan, los levantados en armas buscaban contrarrestar las acusaciones y descalificaciones que se hacían sobre "los desertores", "las hordas serranas" o "las chusmas serranas". Para ello, los "revolucionarios" presentaban su "bandera política” que dotaba de legitimidad a su movimiento. Esa preocupación se percibe en el cuarto punto, en donde se pone énfasis

76 MeYer, El rebelde del norte. 
en la honradez de las tropas serranas y en que esa lucha era justa para mejorar la "condición de los oprimidos”. Con ese mensaje, los serranos mostraban su conocimiento del contexto político y, probablemente, buscaban aliados que se reconocieran en ese mismo escenario y con las mismas filiaciones. La ratificación de esta postura se advierte en la petición de la rendición de la Plaza de Armas de la ciudad de Oaxaca de los jefes revolucionarios al gobernador del estado el 30 de mayo.

A partir de estas reflexiones, lo que interesa destacar es la construcción de una “alegoría revolucionaria” del grupo comandado por Pedro León en alianza con Juan Martínez Carrasco. En los documentos descritos vemos una transformación del discurso del grupo que tomó las armas en mayo de 1912 en la Sierra Juárez. Al parecer en sus inicios, el grupo dirigido por Pedro León -que huía de la ciudad de Oaxaca y se veía amenazado por el jefe político del distrito de Ixtlán-intentó convocar un movimiento general de toda la Sierra contra el gobierno del estado, pero los integrantes del primer batallón no lograron convencer a los ixtlecos. Es posible que en la coyuntura de desprotección y con idea del supuesto envenenamiento de Juárez Maza, y para evitar el desarme, haya comenzado un periodo de guerra que en sus orígenes no buscaba hacer justicia sino que fue un ardid de un grupo que veía su represión y desarme inminente y que por otro lado no tenía más opciones ante el clima de inestabilidad y la posible respuesta de los pueblos que había atacado a fines de 1911.

Nótese que en pocos días esos “desertores” que huyeron sigilosamente de la ciudad de Oaxaca en una noche de abril de 1912, al mes siguiente se organizaron para regresar y atacar a la capital para “poner a un nuevo gobernador”. No sólo se hablaba de defender el distrito, sino que el proyecto consistía en cambiar a las autoridades del estado. Después se presentan las proclamas al grito de la revolución por la inconformidad del pago de los 22 centavos de capitación. Es decir, hay una modificación del 
lenguaje y palabras amoldadas acorde al contexto. Los serranos dejaron de ser los "desertores" de la Primera Compañía del Batallón Sierra Juárez y se presentaron como "revolucionarios".

Gracias a estos pronunciamientos, recopilados en fuentes judiciales, se aprecian pruebas documentales del paulatino desarrollo de un "discurso revolucionario" a partir de manifestaciones textuales de mano de sus protagonistas. Esto permite ver una imagen más completa del surgimiento de un grupo que se transforma en rebelde con gran capacidad para adaptarse al contexto de la revolución. Se observa un proceso de creación de una identidad y formas de presentarse hacia afuera (a las autoridades estatales) y hacia lo local (a las autoridades municipales) en busca de legitimidad.

Lo anterior da pie a poner en duda la interpretación de la "revuelta" ya que no es lo suficientemente sólida. En ese sentido, es importante precisar los conceptos. En la historiografía clásica podemos encontrar que la revuelta es una irrupción violenta y generalizada contra la arbitrariedad de la autoridad en sociedades estratificadas. Uno de los motores principales del acto de rebelarse es hacer público y visible el descontento hacia los grupos dominantes en el gobierno o grupos con poder (económico o político). Entre los factores detonantes de esta acción colectiva se encuentran: insatisfacciones de tipo político, presiones económicas, agravios morales o en algunos momentos sentimientos de injusticia. Por ello, los rebeldes actúan de forma pública con altas dosis de violencia contra los espacios simbólicos de poder, personas poderosas y grupos dominantes. ${ }^{77}$

77 En historia social hay una literatura extensa sobre este tema que incluye a autores como Barrington Moore, E.P. Thompson, Eric Hobsbawm, James Scott y Ranajit Guha, entre otros. Moore, La injusticia; Thompson, Costumbres en común; Новsваwм, Rebeldes primitivos; Scотт, Los dominados; GuHA, Las voces de la historia. En la historiografía mexicanista se encuentran los trabajos de Friedrich Katz, John Tutino, Eric van Young, por mencionar a los más difundidos. Están también los trabajos de Leticia Reina y Francie 
Sin embargo, después de cotejar los distintos documentos del distrito y de rastrear los antecedentes de este levantamiento, puede ser que en vez de una rebelión nos encontremos con un levantamiento armado que se dio por un grupo de pobladores del municipio de Ixtepeji en alianza con otras localidades en una coyuntura muy específica. Es cierto que con el paso de las semanas y la intervención de otros actores la situación inicial se fue transformando, pero queda en duda cuántos municipios participaron como también el número de pobladores que tomaron las armas contra el gobierno por los agravios infligidos contra ellos. Faltaría cuestionar si en efecto esos rebeldes se guiaron por ideales de justicia o por ideas revolucionarias. Aún no es posible documentar sí efectivamente la capitación fue un elemento central.

Por una parte, en la idea de una rebelión abierta y generalizada de los campesinos contra la autoridad local y nacional en busca de mejoras en las condiciones de vida con reclamos de justicia y demandas sociales ya no encaja el acontecimiento analizado. Por otra parte, la idea del levantamiento exclusivo de los ixtepejanos contra Ixtlán tampoco se sostiene puesto que en el conflicto estuvieron inmiscuidos otros pueblos. No se niega que los ixtepejanos fueron mayoría y el centro de operaciones fue la cabecera municipal de Ixtepeji y algunos ranchos aledaños, a lo cual se agrega la intervención de otros pobladores.

En los expedientes judiciales queda constancia de la participación de 39 hombres de Ejutla, Miahuatlán, Tlacolula, Zimatlán y Villa Alta que formaron una cuadrilla armada bajo las órdenes de Pedro León. Este grupo variopinto estuvo al frente de las incursiones en algunas localidades de la Sierra Juárez en la segunda mitad del mes de mayo de 1912. En sus procesos judiciales se

Chassen. Katz, Revuelta, rebelión; Tutino, De la insurrección; VAn Young, La otra rebelión; REINA, Las luchas populares; ReINA, Las rebeliones campesinas; Reina y Abardía, "Cien años de rebelión”; Chassen, Oaxaca. 
encuentra que los involucrados arguyeron que fueron reclutados por la fuerza o por el pago de sus actividades. ${ }^{78}$ Con esto, podemos ver que este levantamiento no se gestó exclusivamente por los ixtepejanos.

Por ello, es complicado aceptar la denominación de "revuelta ixtepejana”, puesto que dudamos que haya sido una revuelta y los ixtepejanos no fueron los únicos implicados en las actividades armadas. Pero si bien el discurso político de Pedro León y su propaganda se fue adecuando y acomodando paulatinamente a las condiciones no quiere decir que no haya tenido efecto. No se puede asegurar que la gente pobre y analfabeta lo siguió sin reticencias ni tampoco se puede afirmar que todos se levantaron en armas contra el mal gobierno por las injusticias y la opresión siguiendo al jefe revolucionario. Esta agitación política y armada se mantuvo más allá de la dirigencia del mismo Pedro León, cuyo desenlace ya se conoce.

\section{CONSIDERACIONES FINALES}

Dentro del amplio espectro de levantamientos armados, ataques entre municipios, asalto a las vías del tren, asesinatos de jefes políticos, quemas de edificios de correos y timbres suscitados en todo el estado de Oaxaca en 1912, destaca lo que pasó en la Sierra Juárez. Como se describió en las páginas precedentes, la prensa de la capital oaxaqueña y de la ciudad de México dieron seguimiento a estas acciones armadas en algunos momentos en primera plana.

En las sesiones del cabildo de Oaxaca fue un tema que ocupó a los síndicos y regidores. Los informes militares registraron detalladamente los ataques y desplazamientos de los rebeldes. Además de ello, queda el registro del juzgado de primera instancia de la ciudad de Oaxaca, donde se sometió a procesos

${ }_{78}$ AHCCJO, C, leg. 519, exp. 3, f. 15. 
criminales a los presuntos sediciosos de forma inmediata y se reunieron los testimonios de algunos involucrados. En años siguientes se encuentran versiones, divergentes en algunos puntos, en las memorias de los participantes.

De primer vistazo, esta "revuelta" se ubica dentro del proceso amplio de la revolución mexicana, pero haciendo una revisión más exhaustiva y confrontando los documentos de la época es posible advertir y cuestionar si estamos frente a una rebelión y si ésta puede denominarse solamente "ixtepejana”. Uno de los puntos centrales de este trabajo fue advertir la forma en que inició este levantamiento armado con la finalidad de observar a los principales participantes y sus proclamas políticas.

Con ello, se destaca que el inicio de este movimiento fue fortuito y circunstancial. En sus orígenes todo comenzó con un grupo que huía ante las represalias del gobierno del estado por la muerte de Benito Juárez Maza. Posteriormente, se fueron gestando ideas y alianzas entre dirigentes, lo que propició un primer intento de toma de armas. En esa coyuntura fue significativo el factor de rivalidad y acercamiento entre municipios. Las diferencias se hicieron patentes y saltó a la palestra un grupo dirigido por el capitán de la primera compañía del Batallón Sierra Juárez.

En este trabajo se observa una transformación de un grupo de "desertores" que se volvieron "rebeldes" y hasta "revolucionarios". Se presenta un detallado análisis de las acciones y los escritos de este grupo. Las evidencias muestran que el grupo que inició el levantamiento armado -los integrantes de la primera compañía del Batallón Sierra Juárez- no tenía un objetivo claro y definido, sino que con el paso de los días y al calor de la coyuntura fueron elaborando un discurso político adecuado al contexto para ganar adeptos y sumar aliados a su grupo. Se pone énfasis en que la primera compañía se componía por personas de distintos municipios. No estaba integrada exclusivamente de personas de Ixtepeji. Por eso, sería complicado creer que los ixtepejanos actuaron solos y sin aliados. A lo anterior se suma 
la presencia de algunos detenidos que no eran de la Sierra Juárez y que provenían de los Valles Centrales.

No se descarta que en medio de todo no hubiera algunas personas con ideas políticas claras ni tampoco insatisfacciones, pero al menos lo que se alcanza a ver es que en poco tiempo un grupo de personas consiguió convocar a más pobladores. Lo que estoy desglosando es que si bien en un inicio los ixtepejanos no fueron los únicos ni tomaron las armas por motivos sociales, no quiere decir que quizá hubo gente que sí lo hizo, sólo que es complicado observar eso en las fuentes.

En el caso de la Sierra Juárez puede advertirse que en esa coyuntura emergieron los problemas de diversa índole a nivel local, que tal vez no solamente eran colectivos sino también personales. Considérese este caso como un ejemplo de los innumerables grupos políticos que aprovecharon el resquebrajamiento del régimen porfiriano para anteponerse a sus enemigos y sacar ventaja. Véase el periodo revolucionario a partir de sus numerosas movilizaciones, sus enfrentamientos y sus ataques alejados de las motivaciones nacionales. Lo que encontramos bajo la denominación de "revuelta ixtepejana" es un levantamiento armado que involucró a distintos actores sociales y que posiblemente articuló diversas demandas locales. Quizá debajo de esta máscara encontremos otro tipo de conflicto o tal vez podemos hablar de una guerra entre estos municipios a nivel regional. Eso se tratará en otro escrito.

\section{SIGLAS Y REFERENCIAS}

AHSDN Archivo Histórico de la Secretaría de la Defensa Nacional, Ciudad de México, México.

AGEO, C Archivo General del Poder Ejecutivo de Oaxaca, Conflictos por límites de tierras, Oaxaca, México.

AHCCJO, J Archivo Histórico de la Casa de la Cultura Jurídica de Oaxaca, Judicial, Oaxaca, México.

BFFB, $M B C, H \quad$ Biblioteca Fray Francisco de Burgoa, fondo Manuel Brioso y Candiani, Hemeroteca, Oaxaca, México. 
AHMO, SM, ACO Archivo Histórico Municipal de Oaxaca de Juárez, Actas de Cabildo, Oaxaca, México.

Acevedo, Esther, Benito Juárez Maza, 1852-1912. Por ser hijo del Benemérito. Una historia fragmentada, México, Instituto Nacional de Antropología e Historia, 2011.

Almada BAy, Ignacio, La conexión Yucupicio: soberania estatal y tradición cívico-liberal en Sonora, 1913-1939, México, El Colegio de México, 2009.

Arellanes Meixueiro, Anselmo, Francie R. Chassen et al., Diccionario bistórico de la revolución en Oaxaca, Oaxaca, Universidad Autónoma Benito Juárez de Oaxaca, Instituto Estatal de Educación Pública de Oaxaca, 1997.

Ávila, Felipe, Los orígenes del zapatismo, México, El Colegio de México, Universidad Nacional Autónoma de México, 2001.

Benjamin, Thomas, “La Revolución es regionalizada”, en Thomas Benjamin y Mark Wasserman (coords.), Historia regional de la revolución mexicana. La provincia entre 1910-1929, México, Consejo Nacional para la Cultura y las Artes, 1996.

Bertrand, Michel y Zacarías Moutoukias, Cambio institucional y fiscalidad. Mundo bispánico, 1760-1850, nueva edición [en línea], Madrid, Casa de Velázquez, 2018 (consultado el 2 de octubre de 2019) http://books.openedition. org/cvz/4289.

Brading, David, Caudillos y campesinos en la Revolución Mexicana, México, Fondo de Cultura Económica, 2005.

Chassen, Francie, Oaxaca entre el liberalismo y la revolución. La perspectiva desde el sur (1867-1911), México, Universidad Autónoma Benito Juárez de Oaxaca, H. Congreso del Estado de Oaxaca, Teatro Macedonio Alcalá, Universidad Autónoma Metropolitana-Iztapalapa, University of Kentucky, 2010.

FAlcón, Romana, El jefe político: un dominio negociado en el mundo rural del Estado de México, 1956-1911, México, El Colegio de México, Centro de Investigaciones y Estudios Superiores en Antropología Social, 2015.

FAlcón, Romana, “El revisionismo revisado”, en Estudios Sociológicos, v: 14 (mayo-ago. 1987), pp. 341-351.

FAlcón, Romana, “Las revoluciones mexicanas de 1910”, en Mexican Studies/ Estudios Mexicanos, 1: 2 (verano 1985), pp. 362-388. 
Falcón, Romana, Revolución y caciquismo. San Luis Potosí, 1910-1938, México, El Colegio de México, 1984.

García Martínez, Bernardo, Las regiones de México. Breviario geográfico e histórico, México, El Colegio de México, 2008.

García Martínez, Bernardo, "México: el conjunto de sus partes”, en GonZÁlez, Rodríguez Valle y Zavala Gómez del Campo (eds.), 2013, pp. 17-25.

Garner, Paul, La Revolución en la provincia. Soberanía estatal y caudillismo en las montañas de Oaxaca (1910-1920), México, Fondo de Cultura Económica, 1988.

Garner, Paul, "Federalism and Caudillismo in the Mexican Revolution: The Genesis of the Oaxaca Sovereignty Movement (1915-20)", en Journal of Latin American Studies, 17: 1 (mayo 1985), pp. 111-133.

González, Aurelio, Nieves Rodríguez Valle y Mercedes Zavala Gómez DEL CAMPo (eds.), Variación regional en la narrativa tradicional de México, México, El Colegio de México, El Colegio de San Luis, 2013,

Guevara Hernández, Jorge, “Arqueología de la Sierra Juárez de Oaxaca”, en M. Winter (comp.), Lecturas históricas del estado de Oaxaca, vol. 1, Época prehispánica, México, Instituto Nacional de Antropología e Historia, 1990, pp. 333-346.

GuHA, Ranajit, Las voces de la historia y otros estudios subalternos, Barcelona, Crítica, 2001.

Hamnett, Brian, "The Caciques of the Oaxaca Sierra, 1824-1884: SubRegion, State and Nation”, en KöNIG y Wiesebron (eds.), 1998, pp. 111-130.

Hobsвawm, Eric, Rebeldes primitivos: estudio sobre las formas arcaicas de los movimientos sociales en los siglos XIX y XX, Barcelona, Crítica, 2001.

IbARra, Isaac, Memorias del general Isaac M. Ibarra. Autobiografía, México, 1975.

Iglesias GonzÁlez, Román (introducción y recopilación), Planes políticos, proclamas, manifiestos y otros documentos de la Independencia al México moderno, 1812-1940, México, Universidad Nacional Autónoma de México, 1998.

Jacobs, I., La revolución mexicana en Guerrero: una revuelta de los rancheros, México, Ediciones Era, 1990. 
Jáuregui, Luis (coord.), De riqueza e inequidad. El problema de las contribuciones directas en América Latina, siglo XIX, México, Instituto Mora, 2006.

Joseph, Gilbert M., Revolución desde afuera: Yucatán, México y Estados Unidos 1880-1924, México, Fondo de Cultura Económica, 1992.

Joseph, G. y Daniel Nugent, Aspectos cotidianos de la formación del Estado, México, Ediciones Era, 2002.

KaTz, Friedrich, Revuelta, rebelión y revolución: la lucha rural en México del siglo XVI al siglo XX, México, Ediciones Era, 1990.

Kearny, Michael, Los vientos de Ixtepeji, México, Instituto Indigenista Interamericano, 1971.

Knight, Alan, La Revolución mexicana. Del porfiriato al nuevo régimen constitucional, México, Fondo de Cultura Económica, 2010.

KNight, Alan, "Caudillos y campesinos en el México revolucionario, 19101917”, en BRADING, 2005, pp. 32-85.

KNIGHT, Alan, "La revolución mexicana: ¿burguesa, nacionalista, o simplemente 'gran rebelión'?”, en Cuadernos Politicos, 48 (oct.-dic. 1986), pp. 5-32.

Knight, Alan y Wil Pansters, Caciquismo in wentieth-Century Mexico, Londres, University of London, Institute for the Study of the Americas, 2005.

KöNIG, Hans-Joachim y Marianne Wiesebron (eds.), Nation-Building in Nineteenth-Century Latin America. Dilemmas and Conflicts, Leiden, Research School CNWS, 1998.

Martínez Medina, Héctor, "Génesis y desarrollo del maderismo en Oaxaca (1909-1912)”, en Martínez VÁsquez (coord.), 1993.

Martínez Vásquez, Víctor Raúl (coord.), La Revolución en Oaxaca 19001930, México, Consejo Nacional para la Cultura y las Artes, 1993.

McNamara, Patrick J., "Felipe García and the Real Heroes of Guelatao", en J. M. Pilcher (ed.), The Human Tradition in Mexico, Wilmington, Delaware, SR Books, 2003.

McNamara, Patrick J., Sons of the Sierra. Juárez, Díaz, and the People of Ixtlán, Oaxaca, 1855-1920, Chapel Hill, The University of North Carolina Press, 2007. 
Menegus, Margarita, "La transformación de la propiedad del antiguo régimen a la propiedad liberal. Consideraciones sobre la capitación y los impuestos sobre la propiedad", en Bertrand y Moutoukias, 2018.

Meyer, Michael C., El rebelde del norte: Pascual Orozco y la revolución, México, Universidad Nacional Autónoma de México, 1984.

Moore, Barrington, La injusticia: bases sociales de la obediencia y la rebelión, México, Universidad Nacional Autónoma de México, 1989.

Pérez García, Rosendo, Una revolución de ocho meses en la Sierra Juárez, Oaxaca, Secretaría de las Culturas y Artes de Oaxaca, 2005.

Pérez Ramírez, Tatiana, "Municipios de la Sierra Juárez: configuración espacial, participación armada y organización política, 1855-1939”, tesis de doctorado en historia, México, El Colegio de México, 2017.

Pineda Gomez, F., A cien años del Plan de Ayala, México, Ediciones Era, Fundación Zapata y los Herederos de la Revolución, 2013.

Purnell, Jennie, "The Chegomista Rebellion in Juchitán, 1911-1912: Rethinking the Role of Traditional Caciques in Resisting State Power", en KNIGHT y PANSTERs, 2005, pp. 51-70.

ReInA, Leticia, Las luchas populares en México en el siglo XIX, México, Secretaría de Educación Pública, Centro de Investigaciones y Estudios Superiores en Antropología Social, 1983.

ReInA, Leticia, La reindianización de América, siglo XIX, México, Siglo Veintiuno Editores, Centro de Investigaciones y Estudios Superiores en Antropología Social, 1997.

ReINA, Leticia (coord.), Las rebeliones campesinas en México (1819-1906), México, Siglo Veintiuno Editores, 1988.

Reina, Leticia y Francisco Abardía, “Cien años de rebelión”, en Winter y Romero Frizzi, 1990, vol. III, pp. 435-494.

Ruiz Cervantes, Francisco José, “El Batallón Sierra Juárez”, Guachachi' Reza (Iguana Rajada), segunda época, 9 (dic. 1981), pp. 16-18.

Ruiz Cervantes, Francisco José, La revolución en Oaxaca: el movimiento de la soberanía, 1915-1920, México, Fondo de Cultura Económica, 1986. 
Ruiz Cervantes, Francisco José, Documentos para la bistoria de la rebelión ixtepejana, s. f.

Sánchez Silva, Carlos, "Conflicto intercomunal, caciquismo/caudillismo y rebelión en Oaxaca, 1912”, en Memoria del Congreso Internacional de la Revolución Mexicana, México, Gobierno del Estado de San Luis Potosí, Instituto Nacional de Estudios Históricos sobre la Revolución Mexicana, 1991, pp. 101-130.

Sánchez Silva, Carlos, Indios, comerciantes y burocracia en la Oaxaca poscolonial, México, Instituto Oaxaqueño de las Culturas, Foro de Economía Social y Colaborativa de Canarias, Universidad Autónoma Benito Juárez de Oaxaca, 1998.

ScotT, James, Los dominados y el arte de la resistencia, México, Ediciones Era, 2000.

Serrano, José Antonio, "Contribuciones directas y reformas fiscales en las regiones de México, 1820-1836”, en Jáuregui (coord.), 2006, pp. 183-224.

Thompson, E. P., Costumbres en común, Barcelona, Crítica, 1995.

Tutino, John, De la insurrección a la revolución en México. Las bases sociales de la violencia agraria, 1750-1940, México, Ediciones Era, 1990.

VAN Young, Eric, La otra rebelión. La lucha por la independencia de México, 1810-1821, México, Fondo de Cultura Económica, 2006.

Waterbury, Ronald, "Non-revolutionary Peasants: Oaxaca Compared to Morelos in the Mexican Revolution", en Comparative Studies in Society and History, xvII: 4 (1975), pp. 410-442.

Winter, Marcus y María de los Ángeles Romero Frizzi, Lecturas históricas del estado de Oaxaca, México, Instituto Nacional de Antropología e Historia, 1990.

Woмack, J., “La Revolución Mexicana, 1910-1920”, en Leslie Bethell, Historia de América Latina, Barcelona, Crítica, 2000, pp. 78-109. 
